\title{
In situ observations of the isotopic composition of methane at the Cabauw tall tower site
}

\author{
Thomas Röckmann ${ }^{1, *}$, Simon Eyer ${ }^{2, *}$, Carina van der Veen ${ }^{1}$, Maria E. Popa ${ }^{1}$, Béla Tuzson ${ }^{2}$, Guillaume Monteil ${ }^{1, a}$, \\ Sander Houweling ${ }^{1}$, Eliza Harris ${ }^{2}$, Dominik Brunner ${ }^{2}$, Hubertus Fischer $^{6}$, Giulia Zazzeri $^{3}$, David Lowry $^{3}$, \\ Euan G. Nisbet ${ }^{3}$, Willi A. Brand ${ }^{4}$, Jaroslav M. Necki ${ }^{5}$, Lukas Emmenegger ${ }^{2}$, and Joachim Mohn ${ }^{2}$ \\ ${ }^{1}$ Utrecht University, Institute for Marine and Atmospheric Research Utrecht, Utrecht, the Netherlands \\ ${ }^{2}$ Empa, Laboratory for Air Pollution/Environmental Technology, Dübendorf, Switzerland \\ ${ }^{3}$ Royal Holloway University of London, Department of Earth Sciences, Egham, UK \\ ${ }^{4}$ Max Planck Institute for Biogeochemistry, Jena, Germany \\ ${ }^{5}$ Environmental Physics Group, Faculty of Physics and Applied Computer Science, AGH University of Science and \\ Technology, Krakow, Poland \\ ${ }^{6}$ University of Bern, Climate and Environmental Physics, Bern, Switzerland \\ ${ }^{a}$ now at: Department of Physical Geography and Ecosystem Science, Lund University, Lund, Sweden \\ *These authors contributed equally to this work.
}

Correspondence to: Thomas Röckmann (t.roeckmann@uu.nl)

Received: 21 January 2016 - Published in Atmos. Chem. Phys. Discuss.: 10 February 2016

Revised: 3 August 2016 - Accepted: 3 August 2016 - Published: 19 August 2016

\begin{abstract}
High-precision analyses of the isotopic composition of methane in ambient air can potentially be used to discriminate between different source categories. Due to the complexity of isotope ratio measurements, such analyses have generally been performed in the laboratory on air samples collected in the field. This poses a limitation on the temporal resolution at which the isotopic composition can be monitored with reasonable logistical effort. Here we present the performance of a dual isotope ratio mass spectrometric system (IRMS) and a quantum cascade laser absorption spectroscopy (QCLAS)-based technique for in situ analysis of the isotopic composition of methane under field conditions. Both systems were deployed at the Cabauw Experimental Site for Atmospheric Research (CESAR) in the Netherlands and performed in situ, high-frequency (approx. hourly) measurements for a period of more than 5 months. The IRMS and QCLAS instruments were in excellent agreement with a slight systematic offset of $(+0.25 \pm 0.04) \%$ for $\delta^{13} \mathrm{C}$ and $(-4.3 \pm 0.4) \%$ for $\delta \mathrm{D}$. This was corrected for, yielding a combined dataset with more than 2500 measurements of both $\delta^{13} \mathrm{C}$ and $\delta \mathrm{D}$. The high-precision and hightemporal-resolution dataset not only reveals the overwhelming contribution of isotopically depleted agricultural $\mathrm{CH}_{4}$
\end{abstract}

emissions from ruminants at the Cabauw site but also allows the identification of specific events with elevated contributions from more enriched sources such as natural gas and landfills. The final dataset was compared to model calculations using the global model TM5 and the mesoscale model FLEXPART-COSMO. The results of both models agree better with the measurements when the TNO-MACC emission inventory is used in the models than when the EDGAR inventory is used. This suggests that high-resolution isotope measurements have the potential to further constrain the methane budget when they are performed at multiple sites that are representative for the entire European domain.

\section{Introduction}

The global increase of the important greenhouse gas methane in the atmosphere since the beginning of the industrial period is very well established (Dlugokencky et al., 2009, 1996, 1998; Etheridge et al., 1998; Khalil et al., 2007; Loulergue et al., 2008; MacFarling Meure et al., 2006; Rasmussen and Khalil, 1981; Spahni et al., 2005). The existing $\mathrm{CH}_{4}$ mole fraction measurement data enable accurate assessment of the 
source-sink imbalance through time and, together with the estimated total sink strength, they allow for a top-down constraint on the global source of methane to the atmosphere (Bergamaschi et al., 2013; Houweling et al., 2014). Bottomup estimates of the global methane budget carry much larger uncertainties, which are inherent to the assumptions made in the extrapolation of local-scale measurements to larger scales (Bruhwiler et al., 2014; Kirschke et al., 2013; Nisbet et al., 2014). The advantage of bottom-up estimates is, however, the possibility to distinguish different sources and to link observations to process-level understanding of the emissions.

An independent approach for distinguishing between source categories of $\mathrm{CH}_{4}$ is the analysis of its isotopic composition, which is strongly linked to the source-sink processes. This is particularly true for methane from biogenic, thermogenic and pyrogenic sources (Gros et al., 2004; Houweling et al., 2008; Quay et al., 1999; Sapart et al., 2012). A more detailed differentiation within one source category, e.g., biogenic $\mathrm{CH}_{4}$, for emissions from wetlands, ruminants, rice paddies or termites, however, is complicated because of the overlap of the respective isotopic source signatures. Further complications arise because individual source signatures can show pronounced dependence on environmental parameters and metabolized substrates (Kawagucci et al., 2014; Klevenhusen et al., 2010). In addition to the source contributions, the sink processes (mainly chemical removal by the hydroxyl radical $(\mathrm{OH})$, but also soil deposition and stratospheric loss) also affect the isotopic composition of atmospheric methane (Brenninkmeijer et al., 1995; Röckmann et al., 2011; Saueressig et al., 1996, 2001; Snover and Quay, 2000). Nevertheless, over the past decades, numerous studies have shown the potential of isotope measurements to identify individual source categories from isotope observations (Beck et al., 2012; Lassey et al., 1993; Tarasova et al., 2006; Umezawa et al., 2012b; Zazzeri et al., 2015) and to constrain budgets (Ferretti et al., 2005; Fischer et al., 2008; Houweling et al., 2008; Lassey et al., 2000; Lowe et al., 1994; Sapart et al., 2012; Umezawa et al., 2012a).

The isotopic composition is commonly reported in $\delta$ notation, where $\delta$ quantifies the relative deviation of an isotope ratio $\left({ }^{13} R={ }^{13} \mathrm{C} /{ }^{12} \mathrm{C}\right.$ for carbon isotopes and ${ }^{2} R={ }^{2} \mathrm{H} /{ }^{1} \mathrm{H}$, abbreviated as $\mathrm{D} / \mathrm{H}$, for hydrogen isotopes) in a sample from a standard ratio. The international standard for reporting $\delta\left({ }^{13} \mathrm{C}, \mathrm{CH}_{4}\right)$ values is Vienna Pee Dee Belemnite (VPDB, ${ }^{13} R_{\mathrm{VPDB}}=0.0112372$; Craig, 1957) and for $\delta\left(\mathrm{D}, \mathrm{CH}_{4}\right)$ it is Vienna Standard Mean Ocean Water $\left(\mathrm{VSMOW},{ }^{2} R_{\text {VSMOW }}=\right.$ 0.0020052; Baertschi, 1976). $\delta\left({ }^{13} \mathrm{C}_{,} \mathrm{CH}_{4}\right)$ and $\delta\left(\mathrm{D}, \mathrm{CH}_{4}\right)$ are abbreviated as $\delta^{13} \mathrm{C}$ and $\delta \mathrm{D}$ in the following and given in per mill (\%o). $\mathrm{CH}_{4}$ mole fractions $\chi\left(\mathrm{CH}_{4}\right)$ are reported in nmol mol ${ }^{-1}=10^{-9}$ and $\mu \mathrm{mol} \mathrm{mol}{ }^{-1}=10^{-6}$. For interpretation of global- or continental-scale atmospheric data the expert group of the WMO/IAEA has set a scientifically desirable level of compatibility of $2 \mathrm{nmol} \mathrm{mol}^{-1}, 0.02$ and $1 \%$ o for $\mathrm{CH}_{4}$ fraction, $\delta^{13} \mathrm{C}$ and $\delta \mathrm{D}$, respectively (WMO, 2014).
For regionally focused studies with large local fluxes, extended compatibility goals of $5 \mathrm{nmol} \mathrm{mol}^{-1}, 0.2$ and $5 \%$ or $\chi\left(\mathrm{CH}_{4}\right), \delta^{13} \mathrm{C}$ and $\delta \mathrm{D}$ were defined.

Due to the complexity of the involved measurement techniques, $\mathrm{CH}_{4}$ isotope measurements have been limited mostly to relatively low-frequency sampling in the field followed by isotope analysis in the laboratory (Bock et al., 2010; Brass and Röckmann, 2010; Sapart et al., 2011; Sperlich et al., 2013; Umezawa et al., 2009; Yamada et al., 2003). For many decades, the dominant method for high-precision isotope analysis of atmospheric methane was isotope ratio mass spectrometry. In particular, the development of continuousflow isotope ratio mass spectrometry (IRMS) in the past 2 decades (Merritt et al., 1994, 1995) has greatly increased the throughput of IRMS methods, making this the technique of choice in most laboratories, also because of the small sample amounts required.

Recently, mid-infrared laser absorption spectroscopy has proven its potential for high-precision isotope ratio analysis. First attempts of measuring the isotopic composition of methane (Bergamaschi et al., 1998a, b, 1994) were restricted to enhanced $\mathrm{CH}_{4}$ mole fractions ( $>50 \mu \mathrm{mol} \mathrm{mol}{ }^{-1}$ for $\delta^{13} \mathrm{C}$ and $>2000 \mu \mathrm{mol} \mathrm{mol}^{-1}$ for $\delta \mathrm{D}$ ) and required cryogenic cooling for both the laser source and the detector, which impeded in situ and long-term applications. The invention of room temperature quantum cascade laser (QCL) sources has triggered the development of a novel generation of spectrometers suitable for in situ analysis of the isotopic composition of greenhouse gases (Eyer et al., 2016; Tuzson et al., 2008; Wächter et al., 2008). Their capability for high temporal resolution led to new applications aiming for source attribution (Mohn et al., 2012; Tuzson et al., 2011; Wolf et al., 2015). The advantages of in situ measurements are particularly apparent in combination with atmospheric modeling techniques, which enables the identification of specific source regions (Rigby et al., 2012; Sturm et al., 2013). Similarly, high-frequency, high-precision $\mathrm{CH}_{4}$ isotope data are expected to greatly reduce uncertainties of national and global source estimations, as demonstrated in an observing system simulation experiment (Rigby et al., 2012).

In this paper we present the analytical setup and results of a 5-month campaign at the Cabauw tall tower site in the Netherlands, where the isotopic composition $\left(\delta^{13} \mathrm{C}\right.$ and $\delta$ D) of $\mathrm{CH}_{4}$ was measured with two instruments, one IRMS system developed at Utrecht University and one quantum cascade laser absorption spectroscopy (QCLAS) instrument developed at Empa. The compatibility of the two analytical techniques for $\mathrm{CH}_{4}$ mole fraction and isotopic composition $\left(\delta^{13} \mathrm{C}\right.$ and $\left.\delta \mathrm{D}\right)$ is assessed and the obtained highresolution isotope dataset is exploited using a novel moving Keeling plot (MKP) method. A comparison of measurement results with calculations from two different models (TM5 and FLEXPART-COSMO) and two emission inventories (EDGAR, TNO-MACC) indicates the potential of this 
approach to better constrain on isotope source signatures and emissions in atmospheric models.

\section{Methods}

\subsection{Site description}

The $213 \mathrm{~m}$ tall tower is the central construction of the Cabauw Experimental Site for Atmospheric Research (CESAR; http://www.cesar-observatory.nl/; $51^{\circ} 58^{\prime} \mathrm{N}, 4^{\circ} 55^{\prime} \mathrm{E}$; $2 \mathrm{~m}$ a.s.l.). CESAR is dedicated to atmospheric research and hosts a wide variety of instruments for in situ and remote sensing measurements of meteorological parameters, trace gases, pollutants, aerosols and clouds. The site is located in an agricultural landscape, with $\mathrm{CH}_{4}$ emissions originating from ruminants and other agricultural activities as well as from the peaty soil and the drainage ditches between the surrounding fields (Peltola et al., 2014). The small town Lopik ( $~ 7500$ inhabitants) is located $1 \mathrm{~km}$ east of the tower. Population and road density increase steeply further away from the tower towards the country's major cities: Utrecht (at about $20 \mathrm{~km}$ distance), Rotterdam $(30 \mathrm{~km})$, the Hague $(40 \mathrm{~km})$ and Amsterdam $(45 \mathrm{~km})$. An estimated 7 million people inhabit these cities and their many neighboring settlements. The location and surroundings are described in more detail in Peltola et al. $(2014,2015)$ and Vermeulen et al. (2011). The instruments were operated in a room on the ground floor of the CESAR building. Since this room is not commonly used as laboratory, it has air conditioning with limited cooling capacity and the temperature varied between 25 and $30^{\circ} \mathrm{C}$.

\subsection{IRMS system}

Air was continuously drawn through $1 / 2$ in. o.d. (outer diameter) Dekabon tubing from $20 \mathrm{~m}$ height at a total flow of $16 \mathrm{~L} \mathrm{~min}^{-1}$ (STP) provided by a Varian scroll pump (Agilent Technologies Inc., USA). The sample gas flow was adjusted by means of a flow restriction at the inlet of the pump in order to maintain the pressure in the sampling line above $950 \mathrm{hPa}$. The sample gas flows for the methane isotope analyzers were branched off upstream of the scroll pump and the restriction, using $1 / 4$ in. o.d. Dekabon lines.

\subsection{Air sampling at the Cabauw tall tower}

The new IRMS method for $\delta^{13} \mathrm{C}$ and $\delta \mathrm{D}$ analysis of atmospheric $\mathrm{CH}_{4}$ is based on the ISAAC system as developed at the Max Planck Institute for Biogeochemistry (MPI-BGC) in Jena (Brand et al., 2016). Importantly, the system does not require liquid nitrogen coolant for the preconcentration and focusing steps but rather uses a massive copper block cooled down to about $-145^{\circ} \mathrm{C}$, to which the cold traps for preconcentration and cryofocusing are connected via standoffs (see Sect. 2.3.1). This cold assembly is contained in an evacuated steel dewar to prevent condensation of moisture. During

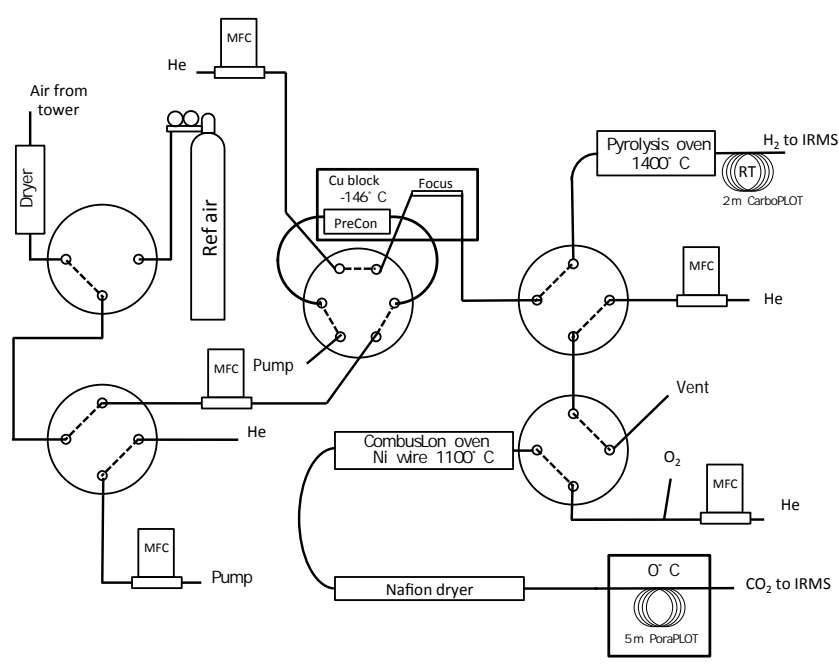

Figure 1. Schematics of the preconcentration and extraction system developed for the IRMS technique. MFC denotes mass flow controller. The eight-port valve through which the reference air cylinder (Ref) was connected to the first selection valve is not shown to reduce complexity. For further description see the main text.

the campaign, the extraction unit and two IRMS instruments (Thermo Delta Plus XL for hydrogen isotopes and Thermo Delta Plus XP for carbon isotopes, both Thermo Fisher Scientific Inc., Germany) were operated at CESAR. The system is schematically shown in Fig. 1.

\subsubsection{Cryogenic trapping}

A Polycold compact cooler compressor (Brooks Automation Inc., USA), filled with coolant PT-30, cooled a cold end on which a copper cylinder $(70 \mathrm{~mm}$ diameter, $85 \mathrm{~mm}$ height, $3 \mathrm{~kg}$ ) was mounted. In this configuration, the copper block reached a temperature of $-145^{\circ} \mathrm{C}$. The preconcentration trap (PreCon) was a $10 \mathrm{~cm}$ length, $1 / 8$ in. o.d. SS tube filled with $4 \mathrm{~cm} \mathrm{60/80} \mathrm{mesh} \mathrm{HayeSep} \mathrm{D} \mathrm{in} \mathrm{the} \mathrm{center}$ and $3 \mathrm{~cm} \mathrm{60/80} \mathrm{glass} \mathrm{beads} \mathrm{on} \mathrm{each} \mathrm{end.} \mathrm{It} \mathrm{was} \mathrm{connected}$ with Valco fittings and the packing material was retained in the trap using removable frits (CEF1F, Valco Instruments Company Inc., USA). The focus trap (Focus) was a $10 \mathrm{~cm}$ length, $1 / 16$ in. o.d. SS tube filled with $2 \mathrm{~cm}$ HayeSep D and $4 \mathrm{~cm}$ glass beads at both ends, connected with Valco fittings (ECEF211.0F, Valco Instruments Company Inc., USA). The traps could be heated with $0.5 \mathrm{~m}$ Thermsys heating wire wrapped around the tubes. The PreCon and Focus trapping units were glued together with a PT-100 temperature sensor in heat-conducting two-component epoxy on a brass standoff. These brass standoffs were mounted to the copper cylinder. In the "trapping" configuration the temperatures of the traps were usually kept at $-135^{\circ} \mathrm{C}$. 


\subsubsection{Measurement procedure}

A three-port two-position Valco valve (3PV, Fig. 1) selected either ambient air drawn from the tower through a $\mathrm{Mg}\left(\mathrm{ClO}_{4}\right)_{2}$ dryer or cylinder air that was injected via one port of an eight-port multi-position Valco valve (MPV). To check the system performance, a reference air cylinder (Ref) was measured alternately with ambient air, and three other target gas cylinders were measured occasionally. The inlet line was connected to a four-port two-position Valco valve (4PV1), which directed either Helium (He, BIP quality, Air Products and Chemicals Inc., USA) or the selected airflow to the PreCon unit, which was connected in the loop position of a six-port two-position Valco valve (6PV). All He and air flows were controlled by MKS mass flow controllers (MFCs; MKS Instruments Inc., USA).

The preconcentration and cryofocusing was done similarly to Brass and Röckmann (2010). After flushing the inlet line with $>20 \mathrm{~mL}$ air, the $6 \mathrm{PV}$ was switched to the load position and air was admitted to the PreCon unit. The duration of the air sampling for the IRMS system was $10 \mathrm{~min}$ at a flow rate of $5 \mathrm{~mL} \mathrm{~min}^{-1}$ for $\delta^{13} \mathrm{C}$ and $7 \mathrm{~mL} \mathrm{~min}^{-1}$ for $\delta \mathrm{D}$ ( $273 \mathrm{~K}, 1$ bar). The flow was provided by a Xavitech mini pump (P200-GAS-12V, Xavitech AB, Sweden). During this step, the temperature measured at the PreCon stayed below $-132^{\circ} \mathrm{C}$. At this temperature $\mathrm{CH}_{4}$ and several other trace species were retained on the HayeSep D, while the air matrix was efficiently flushed out.

After preconcentration, the PreCon unit was heated to $-30^{\circ} \mathrm{C}$ and a He flow of $4 \mathrm{~mL} \mathrm{~min}^{-1}(273 \mathrm{~K}, 1$ bar) transported the $\mathrm{CH}_{4}$ in 90 s to the Focus unit, which was held at a temperature $<-137^{\circ} \mathrm{C}$. After transfer of the sample to the Focus, the 6PV was switched to the load position and the PreCon was heated to $-10^{\circ} \mathrm{C}$ to release any remaining trapped gases such as $\mathrm{CO}_{2}$.

The Focus was then heated to release the $\mathrm{CH}_{4}$, which was directed via 4PV2 and 4VP3 either to the combustion oven and the Delta plus XP IRMS for ${ }^{13} \mathrm{C}$ analysis or to the pyrolysis oven and the Delta plus XL IRMS for D analysis.

For $\delta \mathrm{D}$ analysis, the $\mathrm{CH}_{4}$ was injected into a pyrolysis tube furnace $\left(1400^{\circ} \mathrm{C}\right)$, where $\mathrm{CH}_{4}$ was converted to $\mathrm{H}_{2}$ and carbon. The $\mathrm{H}_{2}$ entered the IRMS, after passing a $2 \mathrm{~m}$ CarboPLOT column at room temperature and a Nafion dryer, via the GasBench interface. No krypton interference (Schmitt et al., 2013) could be determined in this setup. The repeatability for $\delta \mathrm{D}$ was generally better than $2 \%$ (reported as SD), based on consecutive analyses of reference air.

For $\delta^{13} \mathrm{C}$, the $\mathrm{CH}_{4}$ was injected from the cryofocus unit into a combustion oven containing a nickel/nickel oxide wire catalyst at $1100^{\circ} \mathrm{C}$, where the $\mathrm{CH}_{4}$ was converted to $\mathrm{CO}_{2}$ and $\mathrm{H}_{2} \mathrm{O}$. The resulting gas mixture passed a Nafion dryer and a $10 \mathrm{~m}$ PoraPLOT Q column $\left(5^{\circ} \mathrm{C}\right)$ to eliminate interference from co-trapped krypton (Schmitt et al., 2013) before entering the IRMS via the GasBench interface. The re- peatability of $\delta^{13} \mathrm{C}$ was better than $0.07 \%$ (reported as SD), based on consecutive analyses of reference air.

The typical measurement order during the Cabauw campaign was $\operatorname{Ref} \delta^{13} \mathrm{C}-\operatorname{Air} \delta^{13} \mathrm{C}-\operatorname{Ref} \delta \mathrm{D}-\mathrm{Air} \delta \mathrm{D}$. A full measurement cycle took $84 \mathrm{~min}$. On a regular basis, pressurized air from a cylinder, applied as a target gas, was analyzed as a quality-control tool in order to monitor the long-term stability of the analytical technique. The $\mathrm{CH}_{4}$ mole fraction and isotopic composition in ambient air and target gas were calculated using an interpolation of the reference air analyzed before and afterwards. A custom-made LabView software program (National Instruments Corp., USA) was used to control and log the temperature of the traps, the valve switching and the flow set points of the MFCs.

\subsubsection{IRMS system isotope calibration}

The isotope calibration of the IRMS system was based on a reference air cylinder that contains ambient air collected at the IMAU in 2014 , with $1888 \mathrm{nmol} \mathrm{mol}^{-1}$ of $\mathrm{CH}_{4}$ and isotope values of $\delta^{13} \mathrm{C}=(-47.89 \pm 0.05) \%$ and $\delta \mathrm{D}=$ $(-88.08 \pm 1.1) \%$. We used the average of the reference air measurement before and after the sample air measurement to calculate the mole fraction and $\delta$ values. The linear response of the analytical system (independence of the $\delta$ value on the amount of $\mathrm{CH}_{4}$ analyzed) was verified by injecting various volumes of reference air up to a volume equivalent to $2700 \mathrm{nmol} \mathrm{mol}{ }^{-1}$. Occasionally, the long-term stability of the system was checked by measuring three target cylinders with different $\mathrm{CH}_{4}$ mole fractions and isotopic compositions. The $\delta$ values are reported on the recently established scale that links the isotopic composition of methane to the international reference materials VPDB and VSMOW (Sperlich et al., 2016).

\subsection{QCLAS system}

The analytical procedure of the laser-based measurement system involves two steps: preconcentration of the $\mathrm{CH}_{4}$ from $7.5 \mathrm{~L}$ of ambient air in a trace gas extractor (TREX) by adsorption on HayeSep D (Eyer et al., 2014; Mohn et al., 2010) and analysis of $\mathrm{CH}_{4}$ isotopologues with a modified commercial QCLAS (QCL-76-D, Aerodyne Inc., USA). Details on the development, optimization and validation of the TREXQCLAS system are given by Eyer et al. (2016).

The present paper comprises the first application of the TREX-QCLAS system for in situ analysis of $\mathrm{CH}_{4}$ isotopologues at a field site for an extended period of time. In comparison to the original setup, the heating power of the polyimide foil on the cold trap was reduced to $60 \mathrm{~W}$ to increase its lifetime. Due to the lower heating power, the duration of the desorption step had to be extended, which led to an improved separation from residual bulk gases (e.g., $\mathrm{N}_{2}$ and $\mathrm{O}_{2}$ ). Lowering the $\mathrm{O}_{2}$ enhancement in the gas matrix is also the main reason for a lower offset in $\delta^{13} \mathrm{C}$ of $(1.58 \pm 0.1) \%$, 
with respect to the MPI scale, as compared to $2.3 \%$ in previously published results (Eyer et al., 2016). The offset was related to a higher $\mathrm{O}_{2}$ mole fraction in the gas matrix after $\mathrm{CH}_{4}$ preconcentration. One measurement cycle consisted of four consecutive measurements of ambient air samples and one sample of pressurized air used as a target gas, followed by a calibration phase, and took around $4.5 \mathrm{~h}$. This translates into an analysis time of 54 minutes per sample of ambient or pressurized air.

A calibration gas $\left(\mathrm{CG} 1,(1200 \pm 50) \mathrm{mmol} \mathrm{mol}^{-1} \mathrm{CH}_{4}\right.$ in high-purity synthetic air $\left(79.5 \% \mathrm{~N}_{2}\right.$ and $\left.20.5 \% \mathrm{O}_{2}\right) ; \delta^{13} \mathrm{C}$ $=-(44.24 \pm 0.10) \% o, \delta \mathrm{D}=-(104.7 \pm 1.1) \% \circ)$ was diluted with the same synthetic air to $688 \mu \mathrm{mol} \mathrm{mol}^{-1}$ and analyzed between every preconcentrated sample as an anchor to correct the measurements for instrumental drift. A second calibration gas $\left(\mathrm{CG} 2,(1103.8 \pm 3.5) \mu \mathrm{mol} \mathrm{mol}^{-1} \mathrm{CH}_{4} ; \delta^{13} \mathrm{C}\right.$ $=-(36.13 \pm 0.10) \% o, \delta \mathrm{D}=-(180.6 \pm 1.1) \% o)$, diluted to a similar $\mathrm{CH}_{4}$ mole fraction of $681 \mu \mathrm{mol} \mathrm{mol}{ }^{-1}$, was used to calculate calibration factors for $\delta^{13} \mathrm{C}$ and $\delta \mathrm{D}$ values. Furthermore, gas cylinders of pressurized ambient air, referred to as target gas (TG1, TG2), were frequently measured over the entire campaign to determine and verify the repeatability of the measurement system, which was found to be 0.28 and $1.7 \%$ ofor $\delta^{13} \mathrm{C}$ and $\delta \mathrm{D}(1 \sigma)$, respectively. Additional adjustments in the preconcentration procedure and in the analytical routine for isotope analysis improved the repeatability to 0.18 and $0.85 \%$ o for $\delta^{13} \mathrm{C}$ and $\delta \mathrm{D}$ in the last month of the campaign. One example is the improved temperature control of the trap during adsorption, which in turn stabilized the $\mathrm{O}_{2}$ content in the measuring gas and thereby reduced variations in $\delta^{13} \mathrm{C}$.

The isotopic composition of the calibration gases, as well as the target gases $\left(\mathrm{CH}_{4}\right.$ in pressurized air), was determined by the Stable Isotope Laboratory at MPI-BGC. The calibrated values for the target gases are as follows: TG1: $(2639.5 \pm 0.6) \mathrm{nmol} \mathrm{mol}^{-1} \mathrm{CH}_{4}$, $\delta^{13} \mathrm{C}=-(46.48 \pm 0.10) \% o, \quad \delta \mathrm{D}=-(119.0 \pm 1.1) \%$; TG2: $\quad(2659.8 \pm 0.6) \mathrm{nmol} \mathrm{mol}^{-1} \quad \mathrm{CH}_{4}, \quad \delta^{13} \mathrm{C}=$ $-(45.87 \pm 0.10) \% o, \quad \delta \mathrm{D}=-(114.1 \pm 1.1) \%$. $\mathrm{CH}_{4}$ mole fraction measurements were linked to the WMO-X2004 calibration scale (Dlugokencky et al., 2005) through calibration of the target gases against NOAA reference standards at Empa.

\subsection{Modeling}

Two complementary atmospheric transport models (TM5, FLEXPART-COSMO), both in combination with two different emissions inventories (TNO-MACC_2, EDGAR/LPJWHyMe), were applied to support interpretation of the measurements. The Eulerian tracer model TM5 simulated the distribution of $\mathrm{CH}_{4}$ and ${ }^{13} \mathrm{CH}_{4}$ at global scale with a zoom on Europe at $1^{\circ} \times 1^{\circ}$ resolution and considered both the isotopic signatures of different sources and the fractionation by different removal pathways of $\mathrm{CH}_{4}$ in the atmosphere. The
Lagrangian particle dispersion model FLEXPART-COSMO, conversely, was run in backward mode at a higher resolution of $0.06^{\circ} \times 0.06^{\circ}$ but only over Europe. This model is better able to represent the spatial variability of $\mathrm{CH}_{4}$ sources in the near field of Cabauw but it only simulated the contributions from the last 4 days of emissions within Europe and not the large-scale background. Chemical loss of $\mathrm{CH}_{4}$ was not considered due to the short transport times between the sources and the receptor point at Cabauw.

\subsubsection{TM5 modeling}

Simulations of atmospheric $\mathrm{CH}_{4}$ and $\delta^{13} \mathrm{C}$ were performed using the global tracer model TM5 (Krol et al., 2005). The Eularian offline model was driven by meteorological fields from the European Centre for Medium-Range Weather Forecast (ECMWF) reanalysis project ERA-Interim (Dee et al., 2011), preprocessed for use in TM5. For vertical transport due to moist convection we made use of ERA-Interim archived convective mass fluxes, replacing the use of the Tiedke scheme in Krol et al. (2005). The model was run at a horizontal resolution of $6^{\circ} \times 4^{\circ}$ globally and $1^{\circ} \times 1^{\circ}$ inside a zoom domain covering western Europe. The model uses 25 hybrid sigma-pressure levels from the surface to top of atmosphere.

Two parallel (forward) TM5 simulations were performed with $\mathrm{CH}_{4}$ and ${ }^{13} \mathrm{CH}_{4}$ as transported tracers. In the standard configuration, anthropogenic $\mathrm{CH}_{4}$ emissions were taken from EDGAR4.2 FT2010 (EDGAR, 2010), extrapolated to 2014 and 2015 using annual statistics from the Food and Agriculture Organization of the United Nations (FAO) and the British Petroleum Company (BP), as described in Houweling et al. (2014). For natural wetland emissions, an average of the emission estimates derived by Spahni et al. (2011) for the period 2003-2008 was taken, using the LPJ-WHyMe model. For a complete description of the $\mathrm{CH}_{4}$ emissions (Table 1), see Monteil et al. (2013) and references therein. ${ }^{13} \mathrm{CH}_{4}$ emissions were derived from the $\mathrm{CH}_{4}$ emissions using prescribed $\delta^{13} \mathrm{C}$ source signatures (Table 1). The emission inventory was built according to a double constraint: first, each source signature must be chosen within its own uncertainty interval; second, the resulting global average source signature must be compatible with the global source signature that is inferred from the observations (and that is known with a much better precision than the individual source signatures) (Monteil et al., 2011). In a second set of simulations, anthropogenic emissions in a regional domain centered on Cabauw were replaced by emissions from the European TNO-MACC_2 inventory, which was used as the standard inventory in the FLEXPART-COSMO simulations (see below). Outside the regional domain covered by TNOMACC_2, the EDGAR emissions were used.

Atmospheric removal of $\mathrm{CH}_{4}$ was modeled as described in Monteil et al. (2013), using kinetic fractionation factors $\alpha=$ $k\left({ }^{12} \mathrm{C}\right) / k\left({ }^{13} \mathrm{C}\right)$ of $\alpha_{\mathrm{OH}}=1.0055, \alpha_{\mathrm{Cl}}=1.066$ and $\alpha_{\mathrm{O}(1 \mathrm{D})}=$ 
Table 1. European $\mathrm{CH}_{4}$ emissions and isotope source signatures $\left(\delta^{13} \mathrm{C}, \delta \mathrm{D}\right)$ for the different source categories used in TM5. Bold numbers refer to the total of natural, anthropogenic and all emissions, respectively.

\begin{tabular}{|c|c|c|}
\hline Process & $\begin{array}{r}\text { Yearly emissions } \\
\left.\text { (Europe, } \mathrm{Tg} \mathrm{CH} \mathrm{CH}_{4} \mathrm{yr}-1\right)\end{array}$ & $\begin{array}{r}\text { Source signature } \\
\qquad \delta^{13} \mathrm{C} / \% \text { o }\end{array}$ \\
\hline Natural emissions & 22.1 & -59.2 \\
\hline \multicolumn{3}{|l|}{ Natural wetlands ${ }^{\mathrm{a}}$} \\
\hline Peatland & 9.3 & -68 \\
\hline Wet mineral soils & 4.6 & -65 \\
\hline Inundated wetlands & 1.3 & -60 \\
\hline Geological emissions ${ }^{b}$ & 6.5 & -42 \\
\hline Termites $^{c}$ & 0.4 & -63 \\
\hline Anthropogenic emissions & 45.3 & $\mathbf{- 5 2 . 4}$ \\
\hline Biomass burning ${ }^{\mathrm{d}}$ & 0.3 & -23.6 \\
\hline \multicolumn{3}{|l|}{ Agriculture $^{\mathrm{e}}$} \\
\hline Domestic ruminants & 11 & -64 \\
\hline Manure & 3 & -54 \\
\hline Rice paddies & 0.17 & -65 \\
\hline \multicolumn{3}{|l|}{ Energy sector ${ }^{\mathrm{e}}$} \\
\hline Coal mining & 3.4 & -47 \\
\hline Oil production & 3 & -42 \\
\hline Gas production and distribution & 12 & -42 \\
\hline Oil combustion & 0.41 & -32 \\
\hline Residential sector $^{\mathrm{e}}$ & 1.6 & -32 \\
\hline \multicolumn{3}{|l|}{ Waste treatment $\mathrm{e}^{\mathrm{e}}$} \\
\hline Landfills & 9 & -54 \\
\hline Waste waters & 3 & -50 \\
\hline Total & 67.4 & $\mathbf{- 5 4 . 6}$ \\
\hline
\end{tabular}

a Spahni et al. (2011); ${ }^{\mathrm{b}}$ Etiope et al. (2008); ${ }^{\mathrm{c}}$ Sanderson (1996); ${ }^{\mathrm{d}}$ GFED3/4

(http://www.globalfiredata.org/); ${ }^{\mathrm{e}}$ EDGAR4.2FT (EDGAR, 2010).

1.013 for the reactions between $\mathrm{CH}_{4}$ and $\mathrm{OH}$ (Sander et al., 2006), $\mathrm{Cl}$ (Saueressig et al., 1995) and $\mathrm{O}\left({ }^{1} \mathrm{D}\right)$ (Saueressig et al., 2001), respectively. The simulations were initialized at steady state (obtained via a spin-up run) in 2005 , and simulations of the period 2005-2015 were used to calculate a realistic state of the atmosphere at the start of the measurement campaign, including the imbalance between emissions and atmospheric $\mathrm{CH}_{4}$ mixing ratio/isotopic composition in 2014. Time series were extracted from model-simulated mole fraction fields after interpolation to the horizontal coordinate and height of the Cabauw tower air inlet.

\subsubsection{FLEXPART-COSMO modeling}

The Lagrangian particle dispersion model (LPDM) FLEXPART (Stohl et al., 2005) was used in a modified version coupled to the mesoscale numerical weather forecast model COSMO (Baldauf et al., 2011) to simulate the regional contribution of different source categories to the concentrations and isotopic signatures of $\mathrm{CH}_{4}$ at Cabauw. FLEXPARTCOSMO was driven by hourly operational analysis fields generated by the Swiss national weather service MeteoSwiss for a domain covering entire western and central Europe from Ireland, Denmark and Poland in the north to Portugal and southern Italy in the south with a horizontal resolution of approximately $7 \mathrm{~km} \times 7 \mathrm{~km}$ and 60 vertical levels. Every $3 \mathrm{~h}, 50000$ particles (air parcels) were released from the position of the inlet $20 \mathrm{~m}$ above surface and traced backward in time for 4 days to compute the sensitivity of each 3-hourly measurement to upwind sources. The corresponding source sensitivity maps or footprints (Seibert and Frank, 2004) were multiplied with gridded $\mathrm{CH}_{4}$ emissions to compute the mole fraction enhancement above background expected from different sources. Emissions were taken from the TNO-MACC_2 inventory for Europe representative of the year 2009 and available at $0.125^{\circ} \times 0.0625^{\circ}$ resolution (Kuenen et al., 2014) or, alternatively, from the same version of EDGAR/LPJ-WHyMe inventory driving TM5 at a resolution of $1^{\circ} \times 1^{\circ}$. Methane mole fractions were computed separately for a number of SNAP (Standardized Nomenclature for Air Pollutants) source categories with specific isotopic signatures as summarized in Table 2.

For the domain covered by the FLEXPART-COSMO simulations, which includes most of western and central Europe, total anthropogenic emissions are $20.6 \mathrm{Tg} \mathrm{CH}_{4} \mathrm{yr}-1$ in EDGAR and $18.3 \mathrm{Tg} \mathrm{CH}_{4} \mathrm{yr}-1$ in TNO-MACC, which 
Table 2. SNAP (Standardized Nomenclature for Air Pollutants) source categories and corresponding $\delta^{13} \mathrm{C}$ and $\delta \mathrm{D}$ source signatures from the TNO-MACC_2 inventory as used in FLEXPART-COSMO.

\begin{tabular}{|c|c|c|c|}
\hline SNAP category & Description & $\delta^{13} \mathrm{C} / \%$ o & $\delta \mathrm{D} / \%$ \\
\hline 1 & Energy industries, oil or gas production & -42 & -175 \\
\hline 2 & Residential combustion & -32 & -175 \\
\hline $3+4$ & Industrial combustion and non-combustion processes & -60 & -175 \\
\hline 5 & Extraction and distribution of fossil fuels including distribution of natural gas & -42 & -175 \\
\hline 7 & Road transport & -20 & -175 \\
\hline 9 & Waste including emissions from landfills & -54 & -293 \\
\hline 10 & Agriculture including emissions from ruminants and manure management & -64 & -319 \\
\hline $6+8$ & Other emissions (negligible) & -42 & -175 \\
\hline
\end{tabular}

corresponds to a difference of $12.5 \%$. $\mathrm{CH}_{4}$ emissions from gas/oil production and distribution are $89 \%$ higher, $\mathrm{CH}_{4}$ emissions from agriculture $19 \%$ lower and $\mathrm{CH}_{4}$ emissions from waste $12 \%$ higher in EDGAR than in TNO-MACC.

Source-specific emissions were combined with isotopic signatures of the various categories from Table 2 to derive mean $\delta^{13} \mathrm{C}$ and $\delta \mathrm{D}$ isotopic signatures for the $\mathrm{CH}_{4}$ that was picked up by the air parcel along the trajectory.

\subsection{Interpretation of $\mathrm{CH}_{4}$ isotope data}

\subsubsection{Data analysis by a Keeling plot technique}

The isotopic composition of $\mathrm{CH}_{4}$ emissions were estimated using the Keeling plot technique (Keeling, 1961; Pataki et al., 2003). This method allows the isotopic signature of a single source process or the mean isotopic signature of combined source processes that mix into a background reservoir to be determined from the observed ambient isotopic composition and mole fraction. An implicit assumption of the Keeling plot approach is that the isotopic composition and mole fraction of the background reservoir and the isotopic composition of the source or the combined source stay constant over the time range of the analysis. This may not always apply as the relative contribution of individual $\mathrm{CH}_{4}$ sources or their isotopic signature may change over time

To exploit the high temporal resolution of our data, we applied a novel approach of moving Keeling plot (MKP) method. Data within a moving window of $12 \mathrm{~h}$ were used to calculate the source isotopic composition. This window was moved in $1 \mathrm{~h}$ time steps over the data series. In addition, values for background conditions within a $48 \mathrm{~h}$ period, centered on the respective $12 \mathrm{~h}$ window, were included in the analysis. These background values were chosen between 10:00 and 18:00 local time, because during this period a convective boundary layer usually develops and hence local influence is weak; pollution events with $\mathrm{CH}_{4}$ mole fractions above $2100 \mathrm{nmol} \mathrm{mol}^{-1}$ were filtered out additionally. For each time window, an orthogonal least squares fit was applied to the $\delta$ values vs. the inverse $\mathrm{CH}_{4}$ mole fractions and $R^{2}$ values were calculated. A Keeling plot anal- ysis only returns meaningful values for the source isotopic composition if the variations in $\mathrm{CH}_{4}$ mole fraction are significant and if the emissions are from a source with a welldefined isotopic composition. Therefore, two additional filters were applied: (i) the mole fraction had to vary by more than $200 \mathrm{nmol} \mathrm{mol}^{-1}$ within each time window and (ii) the $R^{2}$ of the fit had to be larger than 0.8 . If $R^{2}<0.8$, the $12 \mathrm{~h}$ interval was reduced consecutively by $1 \mathrm{~h}$ to a minimum of $6 \mathrm{~h}$ until either the $R^{2}$ of the fit was $>0.8$ or the number of data points was lower than five. On average this technique accumulated 22 data points per $12 \mathrm{~h}$ time window.

\section{Results}

\subsection{Overview of the field measurements at the Cabauw site}

The full record of the methane mole fraction and isotopic composition obtained with the two measurement techniques at CESAR is shown in Fig. 2. The IRMS system started with $\delta \mathrm{D}$ measurements first and after 3 weeks delivered both $\delta^{13} \mathrm{C}$ and $\delta \mathrm{D}$ data. The TREX-QCLAS system started later and ran continuously from mid-December to mid-January and from mid-February to the end of the campaign. Despite a number of interruptions mainly due to various kinds of instrument malfunction, the combined time series of both techniques shows a high temporal coverage with more than 2500 measurements performed for both $\delta^{13} \mathrm{C}$ and $\delta \mathrm{D}$.

A qualitative inspection of the time series already conveys the obvious features that will be discussed below in more detail: the methane mole fraction $\chi\left(\mathrm{CH}_{4}\right)$ shows a large number of substantial increases above background level, and these positive methane excursions are accompanied by negative excursions in the $\delta$ values from the background level. Thus the additional methane is generally depleted in both ${ }^{13} \mathrm{C}$ and D. 


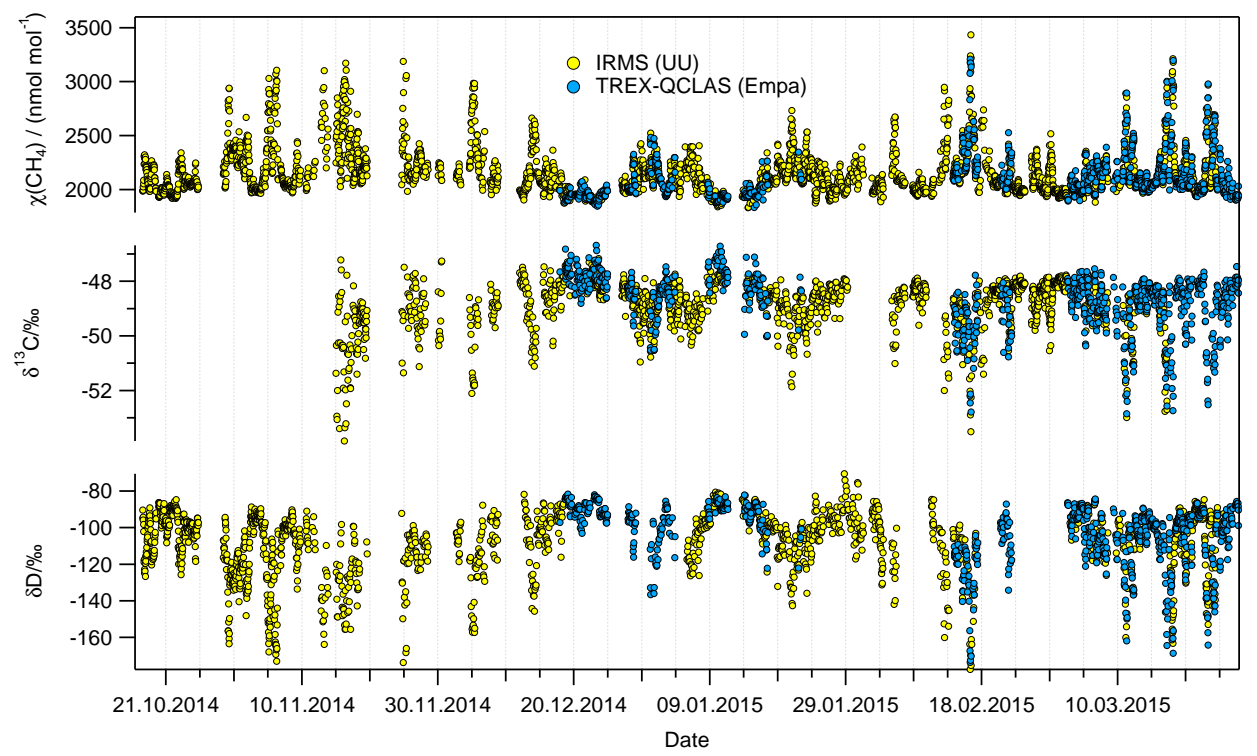

Figure 2. $\mathrm{CH}_{4}$ mole fraction, $\chi\left(\mathrm{CH}_{4}\right)$ and isotopic composition $\left(\delta^{13} \mathrm{C}, \delta \mathrm{D}\right)$ measured at the Cabauw tall tower from 17 October 2014 until 29 March 2015. Real-time measurements by IRMS (Utrecht University) are indicated in yellow, and TREX-QCLAS (Empa) data in blue.

\subsection{Comparison of the two analytical techniques}

Before presenting a detailed analysis of the $\mathrm{CH}_{4}$ isotopic composition in ambient air, we compare the results obtained with the IRMS and QCLAS techniques in order to evaluate their performance and to combine the results into one final dataset. Although both systems measured air from the same intake line, the sampling intervals could not be synchronized since both instruments operated in different measurement cycles. A full measurement cycle (including measurement of the reference gas) took $84 \mathrm{~min}$ for the IRMS system and $54 \mathrm{~min}$ for the TREX-QCLAS system. The actual duration of the air sampling was $10 \mathrm{~min}$ for the IRMS system and $15 \mathrm{~min}$ for the QCLAS system. So even if the systems coincidentally started sampling at the same time, they never actually analyzed exactly the same air mass. Consequently, differences between the systems contain contributions from natural variability, random fluctuations due to limited measurement precision, and system offsets.

Figure 3 shows a comparison of the $\chi\left(\mathrm{CH}_{4}\right)$, as well as $\delta^{13} \mathrm{C}$ and $\delta \mathrm{D}$ values that were obtained with the TREXQCLAS and the IRMS technique. To visualize the possible effect of time shifts, the size of the points corresponds to the proximity of the sampling intervals. A total of 727,333 and 277 measurement pairs for $\chi\left(\mathrm{CH}_{4}\right), \delta^{13} \mathrm{C}$ and $\delta \mathrm{D}$, respectively, analyzed by both techniques, were combined in this way.

The mole fraction comparison shows good agreement along the $1: 1$ line but with a large scatter, which has two contributions: (i) instrumental noise, as the isotope systems have a relatively large uncertainty for measurement of the mole fraction compared to existing high-precision $\mathrm{CH}_{4}$ an- alyzers, and (ii) natural variability associated with the sampling of different air masses as described above. The second point is supported by the fact that the average difference in $\mathrm{CH}_{4}$ mole fractions between the two analytical techniques was larger for larger temporal differences in the sampling intervals.

For the isotope intercalibration plots, the grey-black shading of the circles indicates the difference in $\chi\left(\mathrm{CH}_{4}\right)$ of the respective measurement pair analyzed by both techniques. The overall difference between the measurements conducted with the two systems (QCLAS-IRMS) is $(+0.25 \pm 0.04) \%$ o for $\delta^{13} \mathrm{C}$ and $(-4.3 \pm 0.4) \% o$ for $\delta \mathrm{D}$ (the stated errors are standard errors of the mean). The mean offsets are slightly outside the WMO extended compatibility goals for $\delta^{13} \mathrm{C}(0.2 \%)$ and within the WMO extended compatibility goals for $\delta \mathrm{D}$ $(5 \%$ ), as indicated by the red dashed lines (WMO, 2014). Individual measurement pairs can show significantly larger deviations for aforementioned reasons. Differences between the two techniques are higher than expected as both laboratories refer their measurements to MPI-BGC, who recently established a link between the $\mathrm{CH}_{4}$ isotopic composition and the international reference materials VPDB and VSMOW, in the framework of the INGOS project (Sperlich et al., 2016). Therefore, remaining differences can only be rationalized by uncertainties in propagating the scale or by instrumental issues. The enhanced discrepancies for low $\delta \mathrm{D}$ values might originate from a nonlinear response of one of the applied analytical techniques. The mean offset values determined above were applied to the QCLAS data to create one combined dataset with 2610 data points for $\delta^{13} \mathrm{C}$ and 2673 data points for $\delta \mathrm{D}$. 


\subsection{FLEXPART-COSMO source attribution}
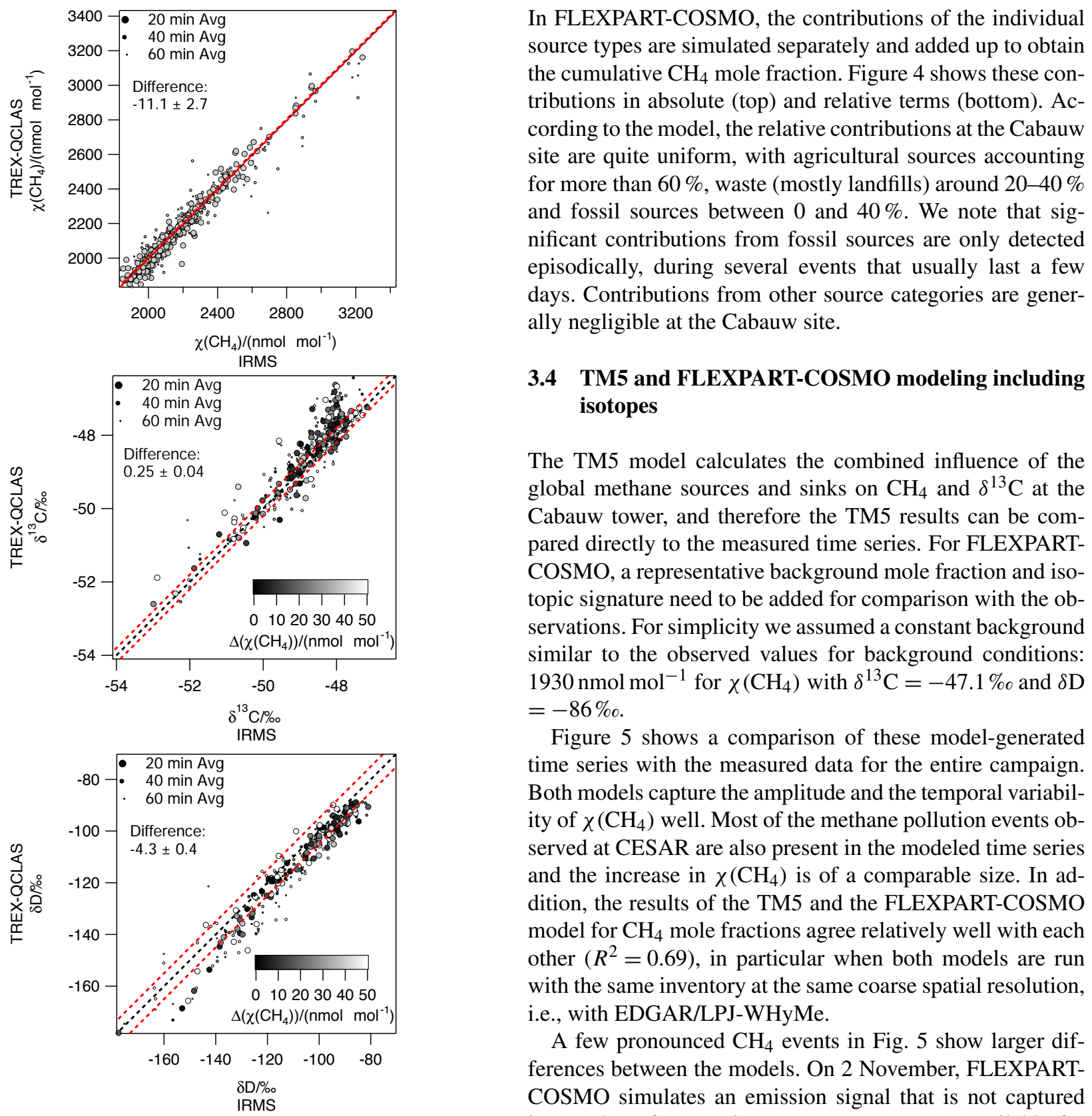

Figure 3. Correlation diagrams for $\mathrm{CH}_{4}$ mole fraction, $\delta^{13} \mathrm{C}$ and $\delta \mathrm{D}$ analyzed with IRMS (Utrecht University) and TREXQCLAS (Empa). The dashed black lines are 1:1 lines; dashed red lines mark the extended WMO compatibility goals of $\pm 5 \mathrm{nmol} \mathrm{mol}^{-1}, \pm 0.2 \%$ and $\pm 5 \%$ o for $\mathrm{CH}_{4}$ mole fraction, $\delta^{13} \mathrm{C}$ and $\delta \mathrm{D}$, respectively. The temporal difference between IRMS and TREX-QCLAS sampling is indicated by the point size (large: $20 \mathrm{~min}$; medium: $40 \mathrm{~min}$; small: $60 \mathrm{~min}$ ). For $\delta^{13} \mathrm{C}$ and $\delta \mathrm{D}$, the differences in the $\mathrm{CH}_{4}$ mole fraction of the measurements are represented by the shading (black: identical mole fractions; white: $50 \mathrm{nmol} \mathrm{mol}^{-1}$ difference).

\subsection{TM5 and FLEXPART-COSMO modeling including isotopes}

The TM5 model calculates the combined influence of the global methane sources and sinks on $\mathrm{CH}_{4}$ and $\delta^{13} \mathrm{C}$ at the Cabauw tower, and therefore the TM5 results can be compared directly to the measured time series. For FLEXPARTCOSMO, a representative background mole fraction and isotopic signature need to be added for comparison with the observations. For simplicity we assumed a constant background similar to the observed values for background conditions: $1930 \mathrm{nmol} \mathrm{mol}^{-1}$ for $\chi\left(\mathrm{CH}_{4}\right)$ with $\delta^{13} \mathrm{C}=-47.1 \%$ and $\delta \mathrm{D}$ $=-86 \%$.

Figure 5 shows a comparison of these model-generated time series with the measured data for the entire campaign. Both models capture the amplitude and the temporal variability of $\chi\left(\mathrm{CH}_{4}\right)$ well. Most of the methane pollution events observed at CESAR are also present in the modeled time series and the increase in $\chi\left(\mathrm{CH}_{4}\right)$ is of a comparable size. In addition, the results of the TM5 and the FLEXPART-COSMO model for $\mathrm{CH}_{4}$ mole fractions agree relatively well with each other $\left(R^{2}=0.69\right)$, in particular when both models are run with the same inventory at the same coarse spatial resolution, i.e., with EDGAR/LPJ-WHyMe.

A few pronounced $\mathrm{CH}_{4}$ events in Fig. 5 show larger differences between the models. On 2 November, FLEXPARTCOSMO simulates an emission signal that is not captured by TM5. Unfortunately no measurements are available for this event to decide on which model performs better. On 30 November TM5 simulates a $\mathrm{CH}_{4}$ plume, which is absent in FLEXPART-COSMO, and this event is also not supported by the measurements. The global model has the advantage that it includes the influence of long-range transport. As expected, however, the observed variability is predominantly influenced by local and regional emissions.

Regarding the time series of the $\delta$ values, both TM5 and FLEXPART-COSMO qualitatively display the expected anticorrelations between $\mathrm{CH}_{4}$ and $\delta^{13} \mathrm{C}$. However, the amplitude of the $\delta^{13} \mathrm{C}$ variability is generally underestimated in the model runs, especially when using the EDGAR inventory. In 


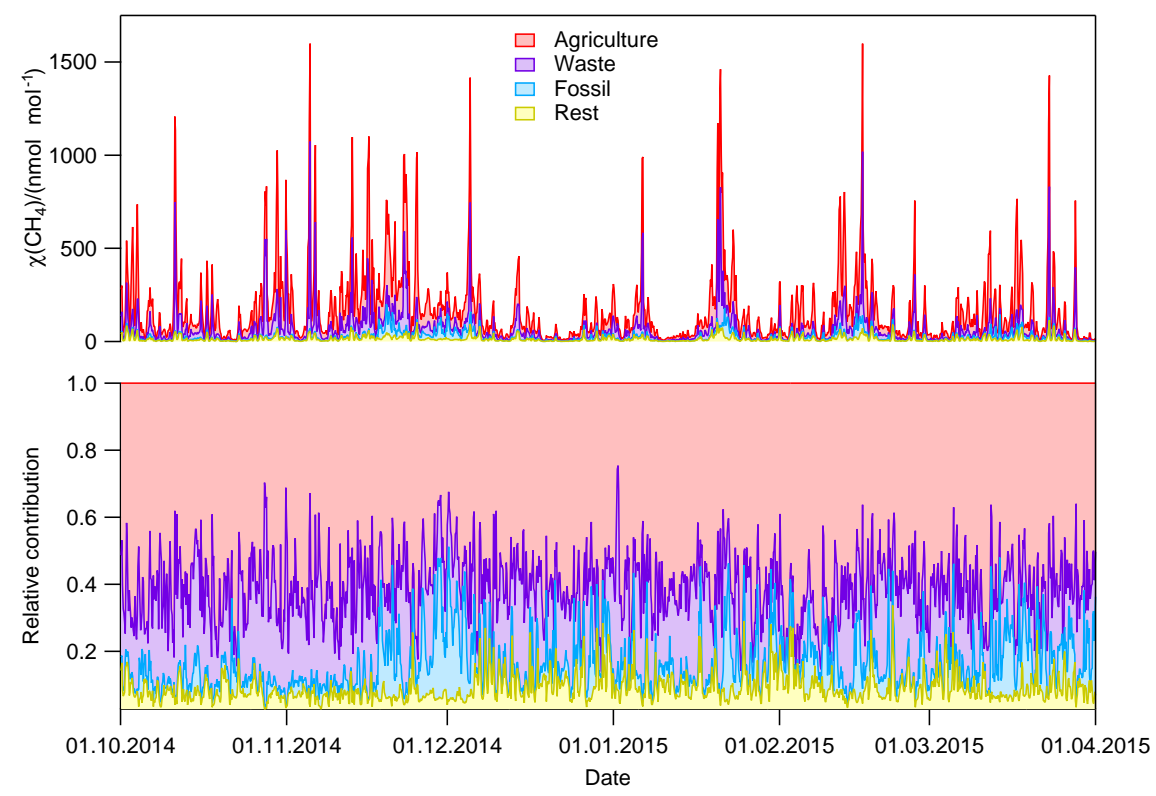

Figure 4. Absolute (top) and relative (bottom) contributions of methane emissions that are picked up along the 4-day FLEXPART-COSMO trajectories during the campaign. The results shown are from the FLEXPART-COSMO simulations with the TNO-MACC inventory. They indicate major contributions of the following source categories: "agriculture" (mainly ruminants), "waste" (mainly landfills) and "fossil" (fugitive losses from coal, oil and natural gas production and from gas transportation and distribution) to the increase in $\mathrm{CH}_{4} \mathrm{~mole}$ fractions at Cabauw. The category "rest" primarily represents residential $\mathrm{CH}_{4}$ emissions.

addition, the modeled background level of $\delta^{13} \mathrm{C}$ in TM5 is offset by up to $1 \%$, but this offset is also present at clean background sites in the Northern Hemisphere.

Using the TNO-MACC inventory in FLEXPART-COSMO results in better agreement with the observed variability of $\delta^{13} \mathrm{C}$. In TM5, the TNO-MACC emissions reduce the amplitude of the $\mathrm{CH}_{4}$ variability, which is explained by the $13 \%$ lower emissions in TNO-MACC compared with EDGAR. Furthermore, the results of both models are consistent with the emissions being more depleted in $\delta^{13} \mathrm{C}$ in TNO-MACC than in EDGAR. The measurements indicate emissions that are even more depleted in $\delta^{13} \mathrm{C}$ than TNO-MACC values. These results suggest that the fractional contribution of isotopically heavy fossil emissions is overestimated in EDGAR, at least in the area sampled by Cabauw, although the uncertainty in the assumed $\delta^{13} \mathrm{C}$ source signatures could also contribute. For instance, recent literature showed that landfill emissions from the UK are more depleted in ${ }^{13} \mathrm{CH}_{4}$ due to the implementation of gas extraction systems (Zazzeri et al., 2015).

The $\delta \mathrm{D}$ time series simulated with FLEXPART-COSMO using the TNO-MACC inventory is in good agreement with the measurements. This further indicates that TNO-MACC has a realistic source mixture, but the uncertainties in the mean $\delta \mathrm{D}$ signature are too large to draw firm conclusions at this stage. Despite these uncertainties, Fig. 5 clearly demonstrates how isotopic measurements highlight differences between emission inventories, which would go unnoticed look- ing only at $\mathrm{CH}_{4}$ mole fractions. Additional information may be available from the combination of both isotope signatures. For several of the $\mathrm{CH}_{4}$ elevation events shown in Fig. $5 \mathrm{~b}$, the relative changes in $\delta^{13} \mathrm{C}$ and $\delta \mathrm{D}$ modeled with FLEXPART-COSMO vary when using the two different inventories (TNO-MACC and EDGAR). Some of the anomalies show differences pointing in the same direction for $\delta^{13} \mathrm{C}$ and $\delta \mathrm{D}$, and some others do not. This suggests that $\delta \mathrm{D}$ provides additional independent information, which will be discussed in more detail in Sect. 4.3 using a double-isotope plot of the source signatures (Fig. 7). The benefit of the highresolution dual isotope measurements for validating emissions used in the models will be investigated in Sect. 4.4.

\section{Discussion}

\subsection{Diurnal and synoptic variability}

A prominent feature of the high-resolution dataset is the pronounced diurnal variability, with large increases in $\mathrm{CH}_{4}$ mole fraction that occur often during the night due to the shallow planetary boundary layer. In addition, there are also several synoptic (but much smaller) pollution events, where $\mathrm{CH}_{4}$ mole fractions stay above the unpolluted background level for several days. These elevations are likely caused by synoptic-scale advection of $\mathrm{CH}_{4}$ plumes from other source regions with a different source mix. 

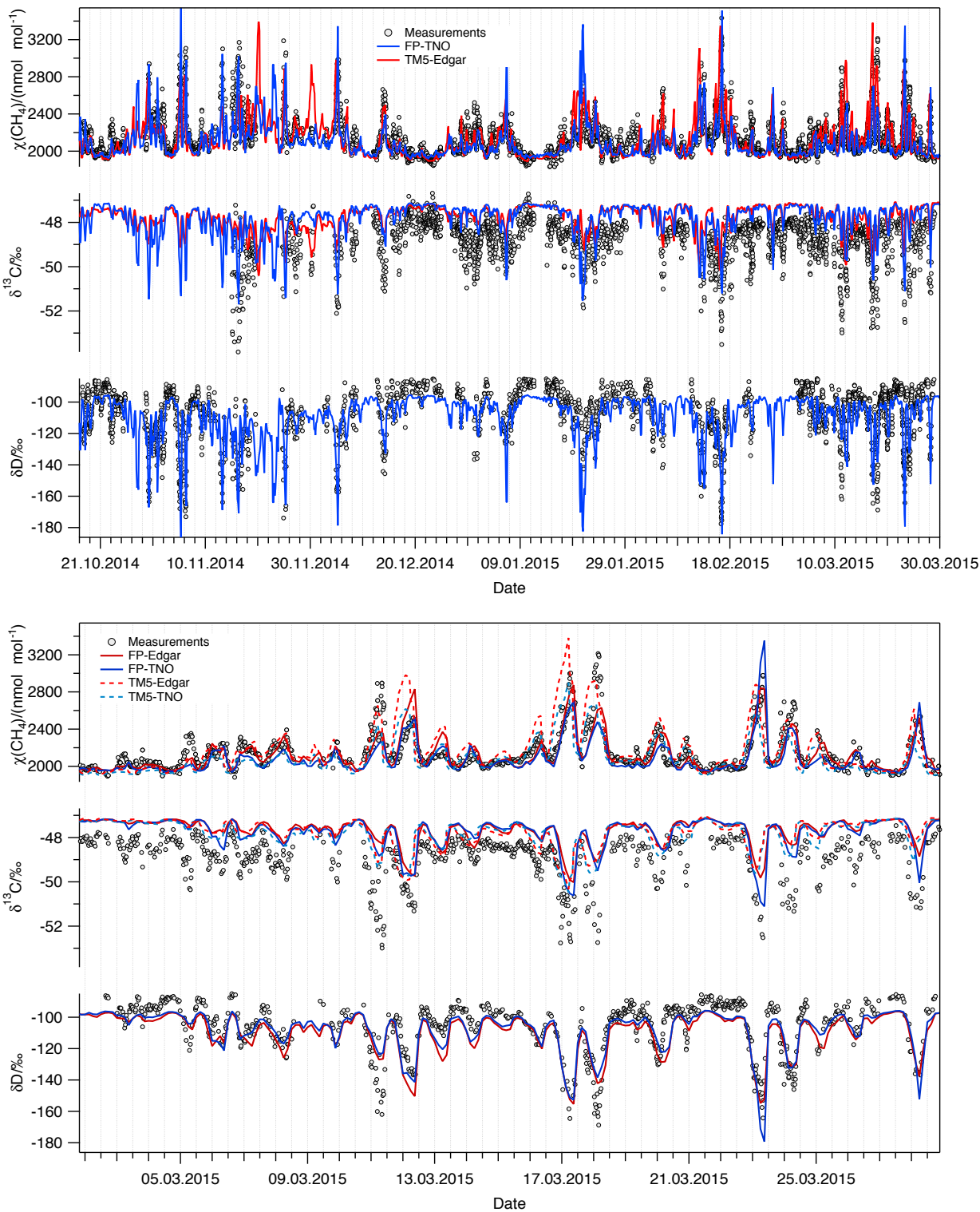

Figure 5. Comparison of the modeled and measured time series of $\mathrm{CH}_{4}$ mole fraction and isotopic composition $\left(\delta^{13} \mathrm{C}\right.$ and $\left.\delta \mathrm{D}\right)$. Measurements are shown as circles and model results as lines. The top graph shows two selected model configurations for the entire campaign: FLEXPARTCOSMO using the TNO-MACC inventory (blue) and TM5 using the Edgar/WHyMe inventory (red). The bottom graph shows time series for March 2015 with all four model-inventory combinations. For $\delta$ D, only the synthetic FLEXPART-COSMO results are available for comparison since TM5 does not simulate $\delta \mathrm{D}$.

\subsection{Isotope identification of the mean $\mathrm{CH}_{4}$ source}

In Fig. 6, the Keeling plot technique is applied to identify the mean isotopic signatures $\left(\delta^{13} \mathrm{C}, \delta \mathrm{D}\right)$ of the combined $\mathrm{CH}_{4}$ emissions detected at the Cabauw site. An orthogonal regression method was applied to determine the fit parameters. This analysis yields well-defined mean isotopic signatures of the cumulative source (the $y$ intercept of the regression analysis) of $\delta^{13} \mathrm{C}=-(60.8 \pm 0.2) \%$ and $\delta \mathrm{D}=-(298 \pm 1) \%$. The inferred mean isotopic signature agrees well with emission from ruminants, which are expected to be the main source of $\mathrm{CH}_{4}$ in this rural area. This is plausible because the mean isotopic signature is largely determined by the pronounced nighttime $\mathrm{CH}_{4}$ elevations, which represent the local emissions close to the tower. Also the source contributions modeled by FLEXPART-COSMO suggest the dominant influence of agricultural emissions in this rural area (Fig. 4). Interestingly, the mean isotopic signature for the much smaller synoptic $\mathrm{CH}_{4}$ variations of the background (red points labeled "Background" in Fig. 6) is not significantly different from the one for the complete dataset. 

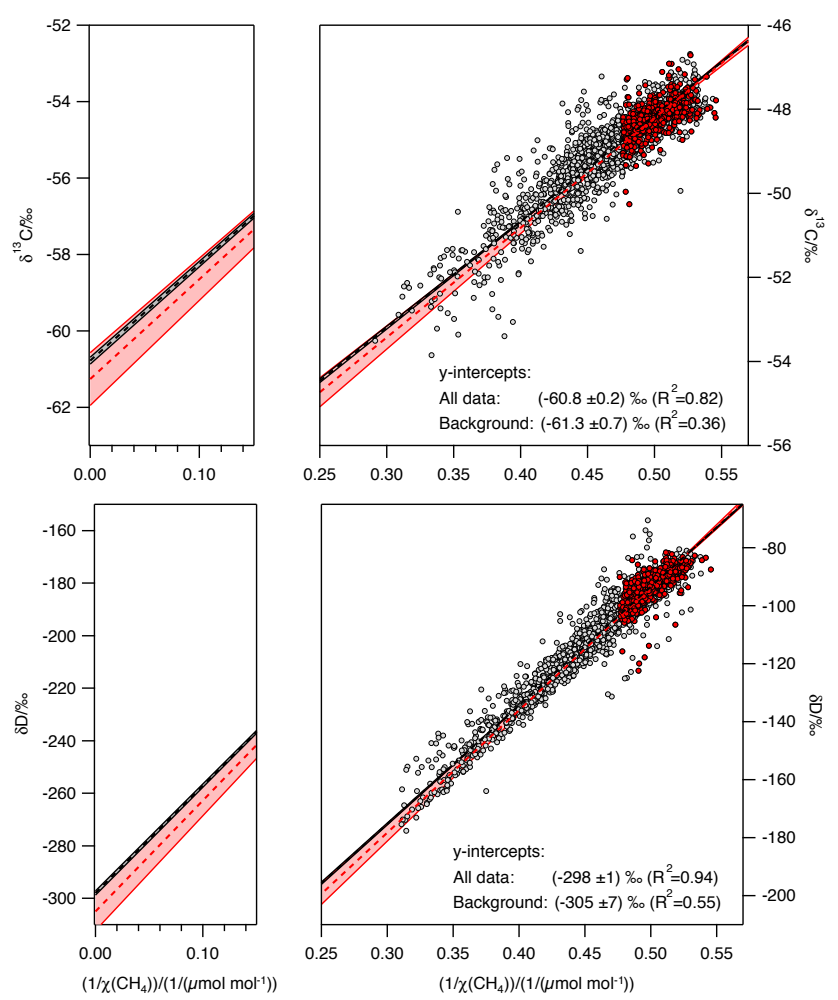

Figure 6. Keeling plot of all data using an orthogonal regression method. The dashed line indicates the regression line and the shaded area the confidence interval taking into account the measurement uncertainties. The color code indicates all measured data (grey points) and daily background values (red points). Left panels show the region near the $y$ axis intercept.

\subsection{Short-term variability}

Given the high temporal resolution of the dataset presented here, the isotope variations can be interpreted in much more detail than the overall analysis performed above. This allows identifying varying contributions of $\mathrm{CH}_{4}$ sources during different periods of the campaign. To do so, we applied a $12 \mathrm{~h}$ MKP method to the data, as described in Sect. 2.6.1.

Figure 7 summarizes the results of the MKP method in the form of a $\delta \mathrm{D}$ vs. $\delta^{13} \mathrm{C}$ plot. To combine $\delta^{13} \mathrm{C}$ and $\delta \mathrm{D}$ measurements performed at different times, MKP intercepts were averaged over $6 \mathrm{~h}$ intervals. Mean $\delta^{13} \mathrm{C}$ signatures range between -68 and $-55 \%$ and mean $\delta \mathrm{D}$ signatures cover a relatively wide range between -350 and $-260 \%$, indicating emissions mainly from microbial sources as derived from the cumulative Keeling plot analysis. During some periods, however, elevated mean $\delta^{13} \mathrm{C}$ and $\delta \mathrm{D}$ signatures reveal significant additional contributions from waste and/or fossil emissions.

The colored symbols in Fig. 7 highlight the mean isotopic signatures of three $48 \mathrm{~h}$ events $(10-12,16-18$ and 22$24 \mathrm{March}$ ) that are discussed in more detail in the following. For the event of 16-18 March, selected results of the $12 \mathrm{~h}$
MKP method are displayed in Fig. 8, demonstrating the advantage of the high-temporal-resolution data. It is possible to clearly distinguish variations in the mean isotopic signatures during this event by variations in the $y$ axis intercepts. The increase by about $6 \%$ for $\delta^{13} \mathrm{C}$ and about $50 \%$ ofor $\delta \mathrm{D}$, in the source isotopic signature for this event, clearly indicates the gradually increasing contribution of $\mathrm{CH}_{4}$ from isotopically enriched sources, e.g., fossil-fuel- or waste-related $\mathrm{CH}_{4}$.

The temporal evolution of the observed source mixture is investigated in further detail in Fig. 9, where the 1618 March period (labeled as 2) is compared to two other $48 \mathrm{~h}$ periods (10-12 March: label 1; 22-24 March: label 3), each with significant diurnal $\mathrm{CH}_{4}$ elevations. For event 1 , the mean isotopic signatures stayed rather constant at values around $\delta^{13} \mathrm{C}=-63 \%$ and $\delta \mathrm{D}=-320 \%$. These values are typical for microbial emissions from an agricultural source and agree well with the source contributions predicted for this period by the FLEXPART-COSMO model.

Period 2 is characterized by much stronger isotopic change within the $48 \mathrm{~h}$ period. The $\delta^{13} \mathrm{C}$ signature increases to above $-60 \%$ and the $\delta \mathrm{D}$ signature increases to $-240 \%$ by the end of the period (see Fig. 9). The double-isotope plot in Fig. 7 shows that the change in $\delta \mathrm{D}$ during event $2 \mathrm{~b}$ clearly points towards fossil fuel sources, which provides independent support for the FLEXPART-COSMO simulations, where the contributions from fossil-fuel-derived emissions are higher for the second day.

For period 3, the mean $\delta^{13} \mathrm{C}$ isotopic signatures increased during the $48 \mathrm{~h}$ by about $2-3 \%$, whereas the $\delta \mathrm{D}$ signatures remained constant around $-300 \%$. For this period, the double-isotope plot of Fig. 7 indeed shows a shift towards the waste category. Also this observation is independently confirmed (at least qualitatively) by the FLEXPART-COSMO model-derived source attribution, which indicates the largest fraction of waste-derived $\mathrm{CH}_{4}$ for the first day and a small addition of fossil $\mathrm{CH}_{4}$ for the second day of event 3. These examples show that even at a location like Cabauw, where one source category strongly dominates, contributions from isotopically different sources can be identified if sufficiently high-resolution dual isotope ratio data are available. We note that the "directional" information in the double-isotope plot is only available by combining $\delta^{13} \mathrm{C}$ and $\delta \mathrm{D}$ measurements. It would be much harder, if not impossible, to distinguish an addition from fossil-fuel- or landfill-derived $\mathrm{CH}_{4}$ based on $\delta^{13} \mathrm{C}$ or $\delta \mathrm{D}$ data alone.

\subsection{Evaluation of emission databases with high-temporal-resolution $\mathrm{CH}_{4}$ isotope data}

As described in Sect. 3.4, both the TM5 and the FLEXPARTCOSMO model-generated time series of $\mathrm{CH}_{4}$ mole fractions show an adequate agreement with the $\mathrm{CH}_{4}$ measurements at the Cabauw site. Therefore, the comparison between measurement data and the models can be used to evaluate the methane budget in more detail. In this con- 


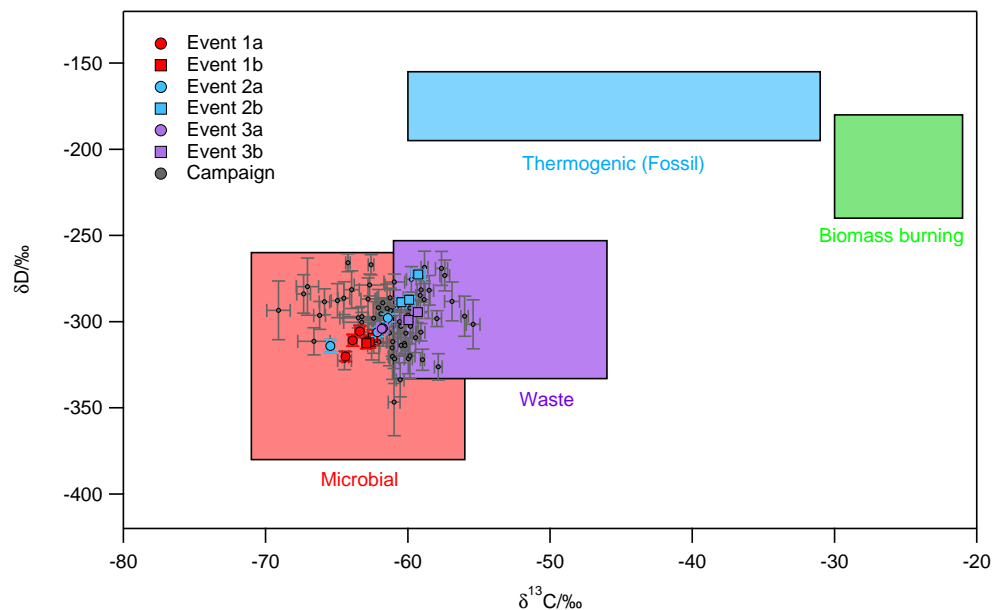

Figure 7. MKP intercepts of $\delta \mathrm{D}$ vs. $\delta^{13} \mathrm{C}$. The colored areas indicate typical isotope signatures for different source categories. Circles show the $6 \mathrm{~h}$-averaged source signatures. Large colored symbols indicate data from the three events (event 1: 10-12 March; event 2: 16-18 March; event 3: 22-24 March) that are highlighted in Fig. 9. The labels a and b refer to day 1 and day 2 of the 2-day events, respectively. For the source signatures, the $\delta^{13} \mathrm{C}$ values are taken from Table 1 and the $\delta \mathrm{D}$ values from recent literature (Snover et al., 2000; Rigby et al., 2012).
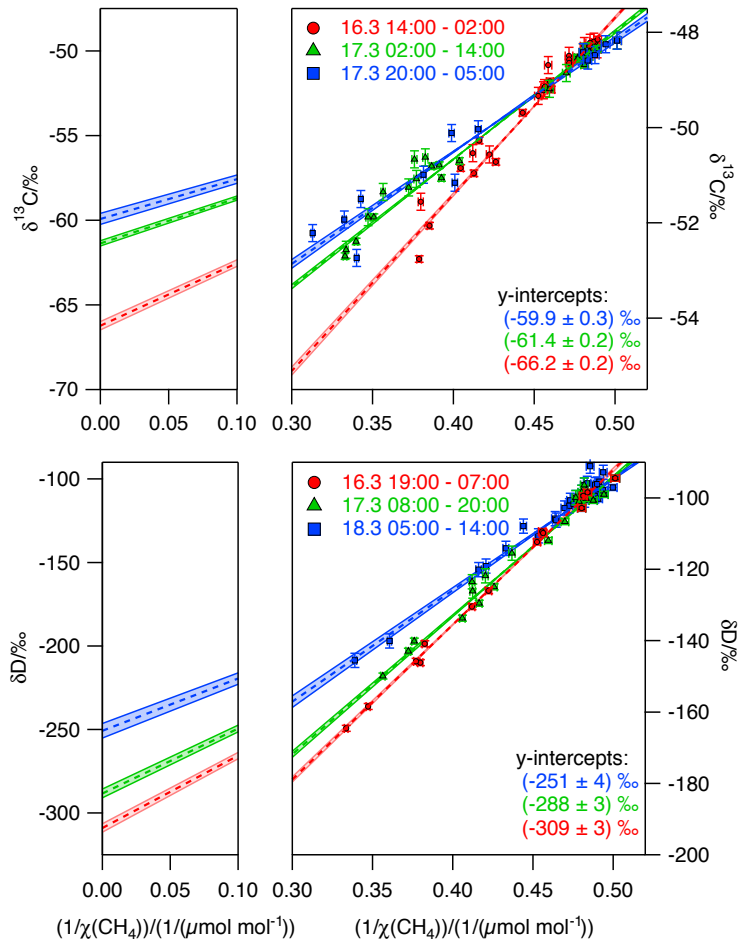

Figure 8. Keeling plots for the period between 16 and 18 March, illustrating a rapid change in $\delta$ values over the course of hours, which is most probably related to a change from mainly ruminant-derived $\mathrm{CH}_{4}$ to a significant contribution of fossil and/or waste $\mathrm{CH}_{4}$. The dashed lines indicate the regression line; the shaded areas show the uncertainty (1 standard deviation) of the regression line. Left panels show the region near the $y$ axis intercept. Times indicated are central European time (CET). text, the measured and modeled isotopic composition can be employed to assess the validity of the emission inventories, EDGAR and TNO-MACC, with respect to the magnitude and spatial distribution of source categories. To compare the measured mean isotopic signatures to the model results, the simulated isotope time series were linearly interpolated and evaluated in the same way as the observations using the $12 \mathrm{~h}$ MKP method. This analysis was performed for both models (TM5 and FLEXPART-COSMO), each using both the EDGAR/LPJ-WHyMe and the TNO_MACC inventories. Additionally, time series for the mean isotopic signatures were calculated directly from FLEXPART-COSMO data, without using of the MKP method. This direct method allowed an independent estimation of the mean isotopic signatures and, thus, also provided an opportunity to evaluate the MKP method.

The statistics of the mean isotopic signatures from all four model-inventory combinations are shown as histograms in Fig. 10, together with the measurement-derived mean isotopic signatures and the directly derived signatures from FLEXPART-COSMO modeling. The numerical values are given in Table 3. A clear difference can be observed between the mean isotopic signatures derived with the two different emission inventories. Model runs with the EDGAR/LPJWHyMe emission inventory (red in Fig. 10) tend to produce mean $\mathrm{CH}_{4}$ isotopic signatures that are more enriched in ${ }^{13} \mathrm{C}$ and $\mathrm{D}$ than the model runs with TNO-MACC emissions. These differences are very similar for the simulations using TM5 and FLEXPART-COSMO, suggesting that differences originate from the emission inventories rather than from differences between the models themselves. The $\delta^{13} \mathrm{C}$ source signatures derived from the measurements at the Cabauw tower are significantly more depleted than any of the model- 


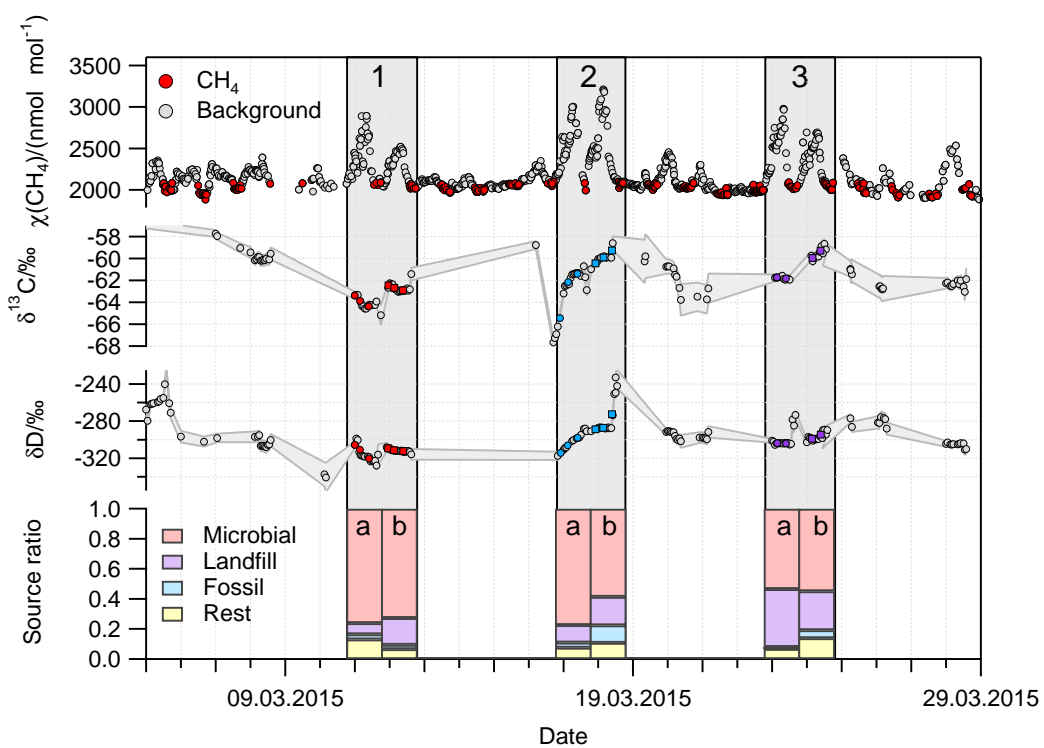

Figure 9. Detailed analysis of three 2-day periods with large $\mathrm{CH}_{4}$ elevations in March 2015. The top panel exhibits $\mathrm{CH}_{4}$ mole fraction (grey) with background values in red $\left(10: 00-18: 00,>2100 \mathrm{nmol} \mathrm{mol}^{-1}\right)$. The middle panels show the mean isotopic signatures $\left(\delta^{13} \mathrm{C}, \delta \mathrm{D}\right)$ derived with the $12 \mathrm{~h}$ MKP method. The color-coding in the middle panels (red, light blue, purple) indicates characteristic contributions from different sources; red is microbial, light blue is fossil and purple is waste. For consistency, the same color-coding was chosen in Fig. 7. The bottom graph presents $\mathrm{CH}_{4}$ source contributions as computed with the FLEXPART-COSMO model using the TNO-MACC inventory, averaged over $24 \mathrm{~h}$.

generated datasets. For $\delta \mathrm{D}$, the mean isotopic signatures using TNO-MACC emissions are relatively close to the measurements at Cabauw, whereas the values using EDGAR emissions are much more enriched in $\mathrm{CH}_{3} \mathrm{D}$.

The high-temporal-resolution isotope data that are described in this paper thus provide relevant information to further constrain models and/or emission inventories because the mean isotopic signatures can change rapidly. The comparison of our first high-resolution isotope measurements at Cabauw to model calculations clearly identifies differences between the modeled inventories, where the EDGAR inventory produced too-enriched mean isotopic signatures due to a higher contribution from fossil fuel sources. Similar differences in terms of source contributions between EDGAR and TNO-MACC_2 were also reported by Hiller et al. (2014) for Switzerland, and Henne et al. (2015) concluded that natural gas emissions in Switzerland are likely overestimated in EDGAR.

\section{Conclusions and outlook}

The dual isotopic composition of $\mathrm{CH}_{4}$ has been monitored for the first time with high temporal resolution in an extended (5 months) field deployment with two different instruments, an IRMS system and a QCLAS system, at the tall tower site in Cabauw, the Netherlands. The measurements of both instruments compare well and can be combined to a time series of more than 2500 measurements for both $\delta^{13} \mathrm{C}$ and $\delta$ D. Using a MKP technique, the mean isotopic signatures of periods with significant $\mathrm{CH}_{4}$ elevations can be derived with high temporal resolution. The combination of $\delta^{13} \mathrm{C}$ and $\delta \mathrm{D}$ data provides strong constraints to distinguish emissions from different source categories. Overall, $\mathrm{CH}_{4}$ emissions at the Cabauw tall tower are dominated by agricultural sources, but variations in the mean isotopic signatures allow identification of events with increased contributions from fossil fuel and waste sources, which can be used to validate variations in the source mix, calculated using the FLEXPART-COSMO model.

The high-resolution isotope ratio measurements at Cabauw were compared to model calculations that used two different emission inventories. When two very different models (TM5 and FLEXPART-COSMO) used emissions from the EDGAR inventory, they produced mean isotopic signatures that are clearly too enriched. The modeled mean isotopic signatures were systematically more depleted and closer to the measured ones when the TNO-MACC inventory was used. The differences in the source signatures appear to originate from differences in the inventories and not from differences in the models, which supports indications in the recent literature that fossil-fuel-related emissions might be overestimated in EDGAR. We note that measurements at Cabauw reflect only one limited region of the European domain, and given the many degrees of freedom (transport, source signatures used in the models, emission inventories), one single dataset is not sufficient to make a final decision on 
Table 3. Mean value and standard deviation of the histograms of the source isotopic composition shown in Fig. 10.

\begin{tabular}{llcc}
\hline Model + inventory & Method & $\delta{ }^{13} \mathrm{C} / \% 0$ & $\delta \mathrm{D} / \% 0$ \\
\hline Measurement data & MKP & $-61.0 \pm 2.8$ & $-300 \pm 22$ \\
TM5 + Edgar & MKP & $-53.3 \pm 1.1$ & \\
FLEXPART-COSMO + Edgar & MKP & $-54.5 \pm 1.6$ & $-277 \pm 10$ \\
FLEXPART-COSMO + Edgar & Direct & $-53.4 \pm 1.7$ & $-269 \pm 10$ \\
TM5 + TNO-MACC & MKP & $-56.7 \pm 0.8$ & \\
FLEXPART-COSMO + TNO-MACC & MKP & $-57.6 \pm 1.9$ & $-294 \pm 12$ \\
FLEXPART-COSMO + TNO-MACC & Direct & $-57.2 \pm 1.7$ & $-289 \pm 11$ \\
\hline
\end{tabular}
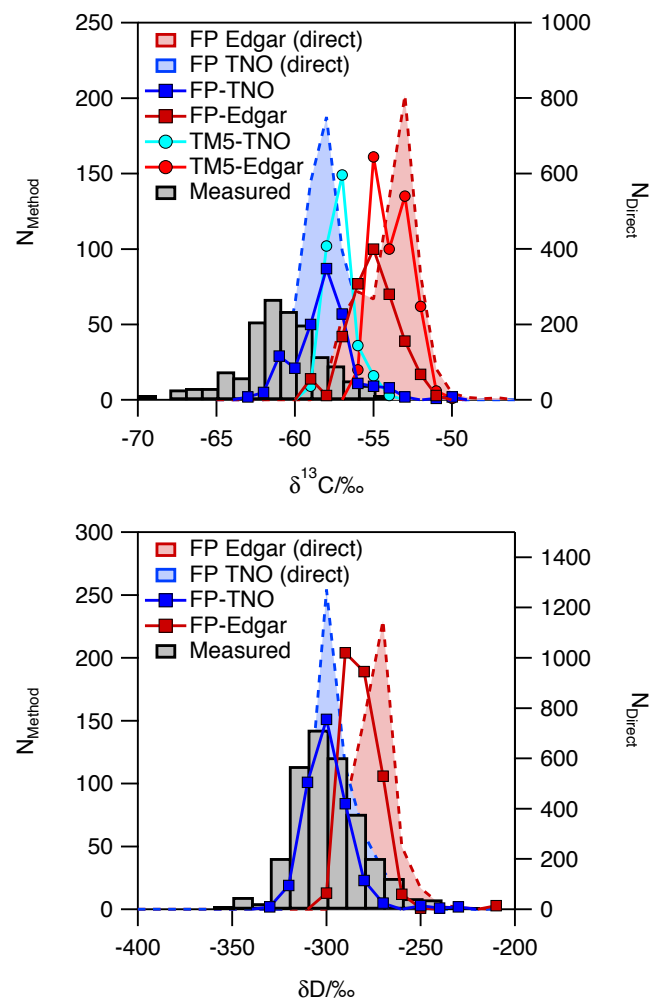

Figure 10. Histograms of $\mathrm{CH}_{4}$ isotope source signatures at CESAR between October 2014 and March 2015. Bin widths are $1 \%$ for $\delta^{13} \mathrm{C}$ and $10 \%$ for $\delta \mathrm{D}$. Mean isotopic signatures are derived from measured data (grey bins), FLEXPART-COSMO modeling (squares) as well as TM5 modeling (circles) using the $12 \mathrm{~h}$ MKP method. Two different inventories, TNO-MACC (blue) and Edgar/LPJ-WHyMe (red), were used. The shaded areas show histograms for the "direct" source signatures that were picked up along the FLEXPART-COSMO trajectory (right axis). Means and standard deviations of these distributions are shown in Table 3.

the quality of the emission dataset. High-frequency analysis of $\delta^{13} \mathrm{C}$ and $\delta \mathrm{D}$ at several locations would allow better constraints on isotope source signatures and emissions in atmospheric models. Our proof-of-concept study presented here using continuous high-resolution techniques shows that this will be feasible in the future.

\section{Data availability}

The data used for the scientific analysis of this paper are available as a Supplement to this paper and at https://www. projects.science.uu.nl/atmosphereclimate/Data.php.

\section{The Supplement related to this article is available online at doi:10.5194/acp-16-10469-2016-supplement.}

Author contributions. S. Eyer and C. van der Veen carried out the isotope measurements at the Cabauw tower. C. van der Veen, T. Röckmann and W. A. Brand developed the IRMS system. S. Eyer, B. Tuzson, L. Emmenegger and J. Mohn developed the TREXQCLAS system. C. van der Veen, S. Eyer, J. Mohn, T. Röckmann, B. Tuzson, M. E. Popa, G. Zazzeri, D. Lowry, E. G. Nisbet and J. M. Necki contributed to the Cabauw measurement campaign. G. Monteil, S. Houweling and D. Brunner performed the modeling with TM5 and FLEXPART-COSMO. S. Eyer, T. Röckmann, J. Mohn, B. Tuzson, E. Harris, D. Brunner, G. Monteil, S. Houweling, C. van der Veen, M. E. Popa and H. Fischer performed and contributed to the data evaluation. S. Eyer produced the figures for the paper. T. Röckmann, S. Eyer and J. Mohn wrote the paper with input from C. van der Veen, G. Monteil, S. Houweling, E. Harris, D. Brunner, H. Fischer and L. Emmenegger. T. Röckmann, L. Emmenegger and J. Mohn designed the study as part of the INGOS project.

Acknowledgements. This project was funded by the European Community's Seventh Framework Program (FP7/2007-2013) within the InGOS project under grant agreement no. 284274. Additional funding from the Swiss National Science Foundation (SNSF) within grant no. 200021_134611 and TNA grants within INGOS is gratefully acknowledged. The campaign at the Cabauw tall tower was made possible with strong support from Marcel Brinkenberg (KNMI), Michel Bolder and Henk Snellen (IMAU). We also thank Marco Weber (Empa) for assistance during transport and setup of the TREX-QCLAS system at CESAR.

Edited by: J. Kaiser

Reviewed by: two anonymous referees 


\section{References}

Baertschi, P.: Absolute ${ }^{18} \mathrm{O}$ content of Standard Mean Ocean Water, Earth Planet. Sci. Lett., 31, 341-344, 1976.

Baldauf, M., Seifert, A., Förstner, J., Majewski, D., Raschendorfer, M., and Reinhardt, T.: Operational Convective-Scale Numerical Weather Prediction with the COSMO Model: Description and Sensitivities, Mon. Weather Rev., 139, 3887-3905, doi:10.1175/MWR-D-10-05013.1, 2011.

Beck, V., Chen, H. L., Gerbig, C., Bergamaschi, P., Bruhwiler, L., Houweling, S., Röckmann, T., Kolle, O., Steinbach, J., Koch, T., Sapart, C. J., van der Veen, C., Frankenberg, C., Andreae, M. O., Artaxo, P., Longo, K. M., and Wofsy, S. C.: Methane airborne measurements and comparison to global models during BARCA, J. Geophys. Res., 117, D15310, doi:10.1029/2011JD017345, 2012.

Bergamaschi, P., Schupp, M., and Harris, G. W.: High-precision direct measurements of ${ }^{13} \mathrm{CH}_{4} /{ }^{12} \mathrm{CH}_{4}$ and $\mathrm{CH}_{3} \mathrm{D} /{ }^{12} \mathrm{CH}_{4}$ ratios in atmospheric methane sources by means of a long-path tunable diode laser absorbtion spectrometer, Appl. Optics, 33, 77047716, 1994.

Bergamaschi, P., Brenninkmeijer, C. A. M., Hahn, M., Röckmann, T., Scharffe, D. H., Crutzen, P. J., Elansky, N. F., Belikov, I. B., Trivett, N. B. A., and Worthy, D. E. J.: Isotope analysis based source identification for atmospheric $\mathrm{CH}_{4}$ and $\mathrm{CO}$ across Russia using the Trans-Siberian railroad, J. Geophys. Res., 103, 82278235, doi:10.1029/97JD03738, 1998a.

Bergamaschi, P., Lubina, C., Konigstedt, R., Fischer, H., Veltkamp, A. C., and Zwaagstra, O.: Stable isotopic signatures $\left(\delta^{13} \mathrm{C}, \delta \mathrm{D}\right)$ of methane from European landfill sites, J. Geophys. Res., 103, 8251-8265, doi:10.1029/98jd00105, 1998b.

Bergamaschi, P., Houweling, S., Segers, A., Krol, M., Frankenberg, C., Scheepmaker, R. A., Dlugokencky, E., Wofsy, S. C., Kort, E. A., Sweeney, C., Schuck, T., Brenninkmeijer, C., Chen, H., Beck, V., and Gerbig, C.: Atmospheric $\mathrm{CH}_{4}$ in the first decade of the 21st century: Inverse modeling analysis using SCIAMACHY satellite retrievals and NOAA surface measurements, J. Geophys. Res.-Atmos., 118, 7350-7369, doi:10.1002/jgrd.50480, 2013.

Bock, M., Schmitt, J., Behrens, M., Moller, L., Schneider, R., Sapart, C., and Fischer, H.: A gas chromatography/pyrolysis/isotope ratio mass spectrometry system for highprecision $\delta \mathrm{D}$ measurements of atmospheric methane extracted from ice cores, Rapid Commun. Mass Sp., 24, 621-633, 2010.

Brand, W. A., Rothe, M., Sperlich, P., Strube, M., and Wendeberg, M.: Automated simultaneous measurement of the $\delta^{13} \mathrm{C}$ and $\delta^{2} \mathrm{H}$ values of methane and the $\delta^{13} \mathrm{C}$ and $\delta^{18} \mathrm{O}$ values of carbon dioxide in flask air samples using a newmulti cryo-trap/gas chromatography/isotope ratio mass spectrometry system, Rapid Commun. Mass Sp., 30, 1523-1539, doi:10.1002/rcm.7587, 2016.

Brass, M. and Röckmann, T.: Continuous-flow isotope ratio mass spectrometry method for carbon and hydrogen isotope measurements on atmospheric methane, Atmos. Meas. Tech., 3, 17071721, doi:10.5194/amt-3-1707-2010, 2010.

Brenninkmeijer, C. A. M., Lowe, D. C., Manning, M. R., Sparks, R. J., and Velthoven, P. F. J. v.: The ${ }^{13} \mathrm{C},{ }^{14} \mathrm{C}$, and ${ }^{18} \mathrm{O}$ isotopic composition of $\mathrm{CO}, \mathrm{CH}_{4}$ and $\mathrm{CO}_{2}$ in the higher southern latitudes lower stratosphere, J. Geophys. Res., 100, 26163-126172, 1995.
Bruhwiler, L., Dlugokencky, E., Masarie, K., Ishizawa, M., Andrews, A., Miller, J., Sweeney, C., Tans, P., and Worthy, D.: CarbonTracker- $\mathrm{CH}_{4}$ : an assimilation system for estimating emissions of atmospheric methane, Atmos. Chem. Phys., 14, 82698293, doi:10.5194/acp-14-8269-2014, 2014.

Craig, H.: Isotopic standards for carbon and oxygen and correction factors for mass-spectrometric analysis of carbon dioxide, Geochim. Cosmochim. Acta, 12, 133-149, 1957.

Dee, D. P., Uppala, S. M., Simmons, A. J., Berrisford, P., Poli, P., Kobayashi, S., Andrae, U., Balmaseda, M. A., Balsamo, G., Bauer, P., Bechtold, P., Beljaars, A. C. M., van de Berg, L., Bidlot, J., Bormann, N., Delsol, C., Dragani, R., Fuentes, M., Geer, A. J., Haimberger, L., Healy, S. B., Hersbach, H., Holm, E. V., Isaksen, L., Kallberg, P., Kohler, M., Matricardi, M., McNally, A. P., Monge-Sanz, B. M., Morcrette, J. J., Park, B. K., Peubey, C., de Rosnay, P., Tavolato, C., Thepaut, J. N., and Vitart, F.: The ERA-Interim reanalysis: configuration and performance of the data assimilation system, Q. J. Roy. Meteor. Soc., 137, 553-579, doi:10.1002/qj.828, 2011.

Dlugokencky, E. J., Dutton, E. G., Novelli, P. C., Tans, P. P., Masarie, K. A., Lantz, K. O., and Madronich, S.: Changes in $\mathrm{CH}_{4}$ and $\mathrm{CO}$ growth rates after the eruption of Mt. Pinatubo and their link with changes in tropical tropospheric UV flux, Geophys. Res. Lett., 23, 2761-2764, 1996.

Dlugokencky, E. J., Masarie, K. A., Lang, P. M., and Tans, P. P.: Continuing decline in the growth rate of the atmospheric methane burden, Nature, 393, 447-450, 1998.

Dlugokencky, E. J., Myers, R. C., Lang, P. M., Masarie, K. A., Crotwell, A. M., Thoning, K. W., Hall, B. D., Elkins, J. W., and Steele, L. P.: Conversion of NOAA atmospheric dry air $\mathrm{CH}_{4}$ mole fractions to a gravimetrically prepared standard scale, J. Geophys. Res., 110, D18306, doi:10.1029/2005jd006035, 2005.

Dlugokencky, E. J., Bruhwiler, L., White, J. W. C., Emmons, L. K., Novelli, P. C., Montzka, S. A., Masarie, K. A., Lang, P. M., Crotwell, A. M., Miller, J. B., and Gatti, L. V.: Observational constraints on recent increases in the atmospheric $\mathrm{CH}_{4}$ burden, Geophys. Res. Lett., 36, L18803, doi:10.1029/2009g1039780, 2009.

EDGAR: European Commission, Joint Research Centre (JRC)/Netherlands Environmental Assessment Agency (PBL), Emission Database for Global Atmospheric Research (EDGAR), Version 4.2., available at: http://edgar.jrc.ec.europa.eu/overview.php?v=42FT2010, 2010.

Etheridge, D. M., Steele, L. P., Francey, R. J., and Langenfelds, R. L.: Atmospheric methane between $1000 \mathrm{AD}$ and present: Evidence of antropogenic emissions and climatic variability, J. Geophys. Res., 103, 15979-15993, 1998.

Etiope, G., Lassey, K. R., Klusman, R. W., and Boschi, E.: Reappraisal of the fossil methane budget and related emission from geologic sources, Geophys. Res. Lett., 35, L09307, doi:10.1029/2008g1033623, 2008.

Eyer, S., Stadie, N. P., Borgschulte, A., Emmenegger, L., and Mohn, J.: Methane preconcentration by adsorption: a methodology for materials and conditions selection, Adsorption-Journal of the International Adsorption Society, 20, 657-666, 2014.

Eyer, S., Tuzson, B., Popa, M. E., van der Veen, C., Röckmann, T., Rothe, M., Brand, W. A., Fisher, R., Lowry, D., Nisbet, E. G., Brennwald, M. S., Harris, E., Zellweger, C., Emmenegger, L., Fischer, H., and Mohn, J.: Real-time analysis of $\delta^{13} \mathrm{C}$ - and $\delta \mathrm{D}$ $\mathrm{CH}_{4}$ in ambient air with laser spectroscopy: method development 
and first intercomparison results, Atmos. Meas. Tech., 9, 263280, doi:10.5194/amt-9-263-2016, 2016.

Ferretti, D., Miller, J., White, J., Etheridge, D., Lassey, K., Lowe, D., Allan, B., MacFarling, C., Dreier, M., Trudinger, C., and Ommen, T. V.: Unexpected changes to the global methane budget over the past 2000 years, Science, 309, 1714-1717, 2005.

Fischer, H., Behrens, M., Bock, M., Richter, U., Schmitt, J., Loulergue, L., Chappellaz, J., Spahni, R., Blunier, T., Leuenberger, M., and Stocker, T. F.: Changing boreal methane sources and constant biomass burning during the last termination, Nature, 452, 864-867, 2008

Gros, V., Brenninkmeijer, C. A. M., Jöckel, P., Kaiser, J., Lowry, D., Nisbet, E. G., O’Brian, P., Röckmann, T., and Warwick, N.: Isotope signatures of trace gas sources. In: Emissions Of Atmospheric Trace Compounds, edited by: Granier, C., Artaxo, P., and Reeves, C. E., Advances in Global Change Research, Kluwer Academic Pub., Paris, 2004.

Henne, S., Brunner, D., Oney, B., Leuenberger, M., Eugster, W., Bamberger, I., Meinhardt, F., Steinbacher, M., and Emmenegger, L.: Validation of the Swiss methane emission inventory by atmospheric observations and inverse modelling, Atmos. Chem. Phys., 16, 3683-3710, doi:10.5194/acp-16-3683-2016, 2016.

Hiller, R. V., Bretscher, D., DelSontro, T., Diem, T., Eugster, W., Henneberger, R., Hobi, S., Hodson, E., Imer, D., Kreuzer, M., Künzle, T., Merbold, L., Niklaus, P. A., Rihm, B., Schellenberger, A., Schroth, M. H., Schubert, C. J., Siegrist, H., Stieger, J., Buchmann, N., and Brunner, D.: Anthropogenic and natural methane fluxes in Switzerland synthesized within a spatially explicit inventory, Biogeosciences, 11, 1941-1959, doi:10.5194/bg-11-1941-2014, 2014.

Houweling, S., van der Werf, G. R., Goldewijk, K. K., Röckmann, T., and Aben, I.: Early anthropogenic $\mathrm{CH}_{4}$ emissions and the variation of $\mathrm{CH}_{4}$ and ${ }^{13} \mathrm{CH}_{4}$ over the last millennium, Global Biogeochem. Cy., 22, Gb1002, doi:10.1029/2007gb002961, 2008.

Houweling, S., Krol, M., Bergamaschi, P., Frankenberg, C., Dlugokencky, E. J., Morino, I., Notholt, J., Sherlock, V., Wunch, D., Beck, V., Gerbig, C., Chen, H., Kort, E. A., Röckmann, T., and Aben, I.: A multi-year methane inversion using SCIAMACHY, accounting for systematic errors using TCCON measurements, Atmos. Chem. Phys., 14, 3991-4012, doi:10.5194/acp-14-39912014, 2014.

Kawagucci, S., Kobayashi, M., Hattori, S., Yamada, K., Ueno, Y., Takai, K., and Yoshida, N.: Hydrogen isotope systematics among $\mathrm{H}_{2}-\mathrm{H}_{2} \mathrm{O}-\mathrm{CH}_{4}$ during the growth of the hydrogenotrophic methanogen Methanothermobacter thermautotrophicus strain Delta H, Geochim. Cosmochim. Ac., 142, 601-614, 2014.

Keeling, C. D.: The Concentration and Isotopic Abundances of Carbon Dioxide in Rural and Marine Air, Geochim. Cosmochim. Ac., 24, 277-298, 1961.

Khalil, M. A. K., Butenhoff, C. L., and Rasmussen, R. A.: Atmospheric methane: Trends and cycles of sources and sinks, Environ. Sci. Technol., 41, 2131-2137, 2007.

Kirschke, S., Bousquet, P., Ciais, P., Saunois, M., Canadell, J. G., Dlugokencky, E. J., Bergamaschi, P., Bergmann, D., Blake, D. R., Bruhwiler, L., Cameron-Smith, P., Castaldi, S., Chevallier, F., Feng, L., Fraser, A., Heimann, M., Hodson, E. L., Houweling, S., Josse, B., Fraser, P. J., Krummel, P. B., Lamarque, J. F., Langenfelds, R. L., Le Quere, C., Naik, V., O’Doherty, S., Palmer, P.
I., Pison, I., Plummer, D., Poulter, B., Prinn, R. G., Rigby, M., Ringeval, B., Santini, M., Schmidt, M., Shindell, D. T., Simpson, I. J., Spahni, R., Steele, L. P., Strode, S. A., Sudo, K., Szopa, S. van der Werf, G. R., Voulgarakis, A., van Weele, M., Weiss, R. F., Williams, J. E., and Zeng, G.: Three decades of global methane sources and sinks, Nat. Geosci., 6, 813-823, 2013.

Klevenhusen, F., Bernasconi, S. M., Kreuzer, M., and Soliva, C. R. Experimental validation of the Intergovernmental Panel on Climate Change default values for ruminant-derived methane and its carbon-isotope signature, Anim. Prod. Sci., 50, 159-167, 2010.

Krol, M., Houweling, S., Bregman, B., van den Broek, M., Segers, A., van Velthoven, P., Peters, W., Dentener, F., and Bergamaschi, P.: The two-way nested global chemistry-transport zoom model TM5: algorithm and applications, Atmos. Chem. Phys., 5, 417432, doi:10.5194/acp-5-417-2005, 2005.

Kuenen, J. J. P., Visschedijk, A. J. H., Jozwicka, M., and Denier van der Gon, H. A. C.: TNO-MACC_II emission inventory; a multiyear (2003-2009) consistent high-resolution European emission inventory for air quality modelling, Atmos. Chem. Phys., 14, 10963-10976, doi:10.5194/acp-14-10963-2014, 2014.

Lassey, K. R., Lowe, D. C., Brenninkmeijer, C. A. M., and Gomez, A. J.: Atmospheric Methane and its Carbon Isotopes in the Southern Hemnisphere: their Time Series and an Instructive Model, Chemosphere, 26, 95-109, 1993.

Lassey, K. R., Lowe, D. C., and Manning, M. R.: The trend in atmospheric methane $\delta^{13} \mathrm{C}$ implications for isotopic constraints on the global methane budget, Global Biogeochem. Cy., 14, 41-49, 2000.

Loulergue, L., Schilt, A., Spahni, R., Masson-Delmotte, V., Blunier, T., Lemieux, B., Barnola, J. M., Raynaud, D., Stocker, T. F., and Chappellaz, J.: Orbital and millennial-scale features of atmospheric $\mathrm{CH}_{4}$ over the past 800,000 years, Nature, 453, 383-386, 2008.

Lowe, D. C., Brenninkmeijer, C. A. M., Brailsford, G. W., Lassey, K. R., Gomez, A. J., and Nisbet, E. G.: Concentration and ${ }^{13} \mathrm{C}$ Records of Atmospheric Methane in New-Zealand and Antarctica - Evidence for Changes in Methane Sources, J. Geophys. Res., 99, 16913-16925, 1994.

MacFarling Meure, C., Etheridge, D., Trudinger, C., Steele, P., Langenfelds, R., Ommen, T. v., Smith, A., and Elkins, J.: Law Dome $\mathrm{CO}_{2}, \mathrm{CH}_{4}$ and $\mathrm{N}_{2} \mathrm{O}$ ice core records extended to 2000 years BP Geophys. Res. Lett., 33, L14810, doi:10.1029/2006GL026152, 2006.

Merritt, D. A., Brand, W. A., and Hayes, J. M.: Isotope-ratiomonitoring gas chromatography-mass spectrometry: methods for isotopic calibration, Org. Geochem., 21, 573-583, 1994.

Merritt, D. A., Hayes, J. M., and Des Marais, D. J.: Carbon isotopic analysis of atmospheric methane by isotope-ratio-monitoring gas chromatography-mass spectrometry, J. Geophys. Res., 100, 1317-1326, 1995.

Mohn, J., Guggenheim, C., Tuzson, B., Vollmer, M. K., Toyoda, S., Yoshida, N., and Emmenegger, L.: A liquid nitrogen-free preconcentration unit for measurements of ambient $\mathrm{N}_{2} \mathrm{O}$ isotopomers by QCLAS, Atmos. Meas. Tech., 3, 609-618, doi:10.5194/amt3-609-2010, 2010.

Mohn, J., Tuzson, B., Manninen, A., Yoshida, N., Toyoda, S., Brand, W. A., and Emmenegger, L.: Site selective real-time measurements of atmospheric $\mathrm{N}_{2} \mathrm{O}$ isotopomers by laser spec- 
troscopy, Atmos. Meas. Tech., 5, 1601-1609, doi:10.5194/amt5-1601-2012, 2012.

Monteil, G., Houweling, S., Dlugockenky, E. J., Maenhout, G., Vaughn, B. H., White, J. W. C., and Röckmann, T.: Interpreting methane variations in the past two decades using measurements of $\mathrm{CH}_{4}$ mixing ratio and isotopic composition, Atmos. Chem. Phys., 11, 9141-9153, doi:10.5194/acp-11-9141-2011, 2011.

Monteil, G., Houweling, S., Butz, A., Guerlet, S., Schepers, D., Hasekamp, O., Frankenberg, C., Scheepmaker, R., Aben, I., and Röckmann, T.: Comparison of $\mathrm{CH}_{4}$ inversions based on 15 months of GOSAT and SCIAMACHY observations, J. Geophys. Res., 118, GB4009, doi:4010.1029/2011GB004232, 2013.

Nisbet, E. G., Dlugokencky, E. J., and Bousquet, P.: Methane on the rise - again, Science, 343, 493-495, 2014.

Pataki, D. E., Ehleringer, J. R., Flanagan, L. B., Yakir, D., Bowling, D. R., Still, C. J., Buchmann, N., Kaplan, J. O., and Berry, J. A.: The application and interpretation of Keeling plots in terrestrial carbon cycle research, Global Biogeochem. Cy., 17, 1022, doi:10.1029/2001GB001850, 2003.

Peltola, O., Hensen, A., Helfter, C., Belelli Marchesini, L., Bosveld, F. C., van den Bulk, W. C. M., Elbers, J. A., Haapanala, S., Holst, J., Laurila, T., Lindroth, A., Nemitz, E., Röckmann, T., Vermeulen, A. T., and Mammarella, I.: Evaluating the performance of commonly used gas analysers for methane eddy covariance flux measurements: the InGOS inter-comparison field experiment, Biogeosciences, 11, 3163-3186, doi:10.5194/bg-113163-2014, 2014.

Peltola, O., Hensen, A., Marchesini, L. B., Helfter, C., Bosveld, F. C., van den Bulk, W. C. M., Haapanala, S., van Huissteden, J., Laurila, T., Lindroth, A., Nemitz, E., Röckmann, T., Vermeulen, A. T., and Mammarella, I.: Studying the spatial variability of methane flux with five eddy covariance towers of varying height, Agr. Forest Meteorol., 214, 456-472, 2015.

Quay, P., Stutsman, J., Wilbur, D., Snover, A., Dlugokencky, E., and Brown, T.: The isotopic composition of atmospheric methane, Global Biogeochem. Cy., 13, 445-461, 1999.

Rasmussen, R. A. and Khalil, M. A. K.: Atmospheric Methane $\left(\mathrm{CH}_{4}\right)$ - Trends and Seasonal Cycles, J. Geophys. Res., 86, 9826-9832, 1981.

Rigby, M., Manning, A. J., and Prinn, R. G.: The value of highfrequency, high-precision methane isotopologue measurements for source and sink estimation, J. Geophys. Res., 117, D12312, doi:10.1029/2011JD017384, 2012.

Röckmann, T., Brass, M., Borchers, R., and Engel, A.: The isotopic composition of methane in the stratosphere: high-altitude balloon sample measurements, Atmos. Chem. Phys., 11, 13287-13304, doi:10.5194/acp-11-13287-2011, 2011.

Sander, S. P., Friedl, R. R., Golden, D. M., Kurylo, M. J., Moortgat, G. K., Keller-Rudek, H., Wine, P. H., Ravishankara, A. R., Kolb, C. E., Molina, M. J., Finlayson-Pitts, B. J., Huie, R. E., and Orkin, V. L.: Chemical Kinetics and Photochemical Data for Use in Atmospheric Studies, Evaluation Number 15, JPL Publication 06-2, Jet Propulsion Laboratory, Pasadena, 2006.

Sanderson, M. G.: Biomass of termites and their emissions of methane and carbon dioxide: A global database, Global Biogeochem. Cy., 10, 543-557, 1996.

Sapart, C. J., van der Veen, C., Vigano, I., Brass,, M., van de Wal, R. S. W., Bock, M., Fischer, H., Sowers, T., Buizert, C., Sperlich, P., Blunier, T., Behrens, M., Schmitt, J., Seth, B., and Röckmann,
T.: Simultaneous stable isotope analysis of methane and nitrous oxide on ice core samples, Atmos. Meas. Tech., 4, 2607-2618, doi:10.5194/amt-4-2607-2011, 2011.

Sapart, C. J., Monteil, G., Prokopiou, M., van de Wal, R. S. W., Kaplan, J. O., Sperlich, P., Krumhardt, K. M., van der Veen, C., Houweling, S., Krol, M. C., Blunier, T., Sowers, T., Martinerie, P., Witrant, E., Dahl-Jensen, D., and Röckmann, T.: Natural and anthropogenic variations in methane sources during the past two millennia, Nature, 490, 85-88, 2012.

Saueressig, G., Bergamaschi, P., Crowley, J. N., Fischer, H., and Harris, G. W.: Carbon kinetic isotope effect in the reaction of CH4 with $\mathrm{Cl}$ atoms, Geophys. Res. Lett., 22, 1225-1228, 1995.

Saueressig, G., Bergamaschi, P., Crowley, J. N., Fischer, H., and Harris, G. W.: D/H kinetic isotope effect in the reaction $\mathrm{CH}_{4}+$ Cl, Geophys. Res. Lett., 23, 3619-3622, 1996.

Saueressig, G., Crowley, J. N., Bergamaschi, P., Brühl, C., Brenninkmeijer, C. A. M., and Fischer, H.: Carbon 13 and D kinetic isotope effects in the reactions of $\mathrm{CH}_{4}$ with $\mathrm{O}\left({ }^{1} \mathrm{D}\right)$ and $\mathrm{OH}$ : New laboratory measurements and their implications for the isotopic composition of stratospheric methane, J. Geophys. Res., 106, 23127-23138, 2001.

Schmitt, J., Seth, B., Bock, M., van der Veen, C., Möller, L., Sapart, C. J., Prokopiou, M., Sowers, T., Röckmann, T., and Fischer, H.: On the interference of $\mathrm{Kr}$ during carbon isotope analysis of methane using continuous-flow combustion-isotope ratio mass spectrometry, Atmos. Meas. Tech., 6, 1425-1445, doi:10.5194/amt-6-1425-2013, 2013.

Seibert, P. and Frank, A.: Source-receptor matrix calculation with a Lagrangian particle dispersion model in backward mode, Atmos. Chem. Phys., 4, 51-63, doi:10.5194/acp-4-51-2004, 2004.

Snover, A. K. and Quay, P. D.: Hydrogen and carbon kinetic isotope effects during soil uptake of atmospheric methane, Global Biogeochem. Cy. 14, 25-39, 2000.

Spahni, R., Chappellaz, J., Stocker, T. F., Loulergue, L., Hausammann, G., Kawamura, K., Flückiger, J., Schwander, J., Raynaud, D., Masson-Delmotte, V., and Jouzel, J.: Atmospheric Methane and Nitrous Oxide of the Late Pleistocene from Antarctic Ice Cores, Science, 310, 1317-1321, doi:10.1126/science.1120132, 2005.

Spahni, R., Wania, R., Neef, L., van Weele, M., Pison, I., Bousquet, P., Frankenberg, C., Foster, P. N., Joos, F., Prentice, I. C., and van Velthoven, P.: Constraining global methane emissions and uptake by ecosystems, Biogeosciences, 8, 1643-1665, doi:10.5194/bg8-1643-2011, 2011.

Sperlich, P., Buizert, C., Jenk, T. M., Sapart, C. J., Prokopiou, M., Röckmann, T., and Blunier, T.: An automated GC-C-GC-IRMS setup to measure palaeoatmospheric $\delta^{13} \mathrm{C}^{-} \mathrm{CH}_{4}, \delta^{15} \mathrm{~N}-\mathrm{N}_{2} \mathrm{O}$ and $\delta^{18} \mathrm{O}-\mathrm{N}_{2} \mathrm{O}$ in one ice core sample, Atmos. Meas. Tech., 6, 20272041, doi:10.5194/amt-6-2027-2013, 2013.

Sperlich, P., Uitslag, N. A. M., Richter, J. M., Rothe, M., Geilmann, H., van der Veen, C., Röckmann, T., Blunier, T., and Brand, W. A.: Development and evaluation of a suite of isotope reference gases for methane in air, Atmos. Meas. Tech., 9, 3717-3737, doi:10.5194/amt-9-3717-2016, 2016.

Stohl, A., Forster, C., Frank, A., Seibert, P., and Wotawa, G.: Technical note: The Lagrangian particle dispersion model FLEXPART version 6.2, Atmos. Chem. Phys., 5, 2461-2474, doi:10.5194/acp-5-2461-2005, 2005. 
Sturm, P., Tuzson, B., Henne, S., and Emmenegger, L.: Tracking isotopic signatures of $\mathrm{CO}_{2}$ at the high altitude site Jungfraujoch with laser spectroscopy: analytical improvements and representative results, Atmos. Meas. Tech., 6, 1659-1671, doi:10.5194/amt-6-1659-2013, 2013.

Tarasova, O. A., Brenninkmeijer, C. A. M., Assonov, S. S., Elansky, N. F., Röckmann, T., and Brass, M.: Atmospheric $\mathrm{CH}_{4}$ along the Trans-Siberian railroad (TROICA) and river Ob: Source identification using stable isotope analysis, Atmos. Environ., 40, 56175628, 2006.

Tuzson, B., Mohn, J., Zeeman, M. J., Werner, R. A., Eugster, W., Zahniser, M. S., Nelson, D. D., McManus, J. B., and Emmenegger, L.: High precision and continuous field measurements of $\delta^{13} \mathrm{C}$ and $\delta^{18} \mathrm{O}$ in carbon dioxide with a cryogen-free QCLAS, Appl. Phys. B-Lasers O., 92, 451-458, 2008.

Tuzson, B., Henne, S., Brunner, D., Steinbacher, M., Mohn, J., Buchmann, B., and Emmenegger, L.: Continuous isotopic composition measurements of tropospheric $\mathrm{CO}_{2}$ at Jungfraujoch (3580 m a.s.l.), Switzerland: real-time observation of regional pollution events, Atmos. Chem. Phys., 11, 1685-1696, doi:10.5194/acp-11-1685-2011, 2011.

Umezawa, T., Aoki, S., Nakazawa, T., and Morimoto, S.: A Highprecision Measurement System for Carbon and Hydrogen Isotopic Ratios of Atmospheric Methane and Its Application to Air Samples Collected in the Western Pacific Region, J. Meteorol. Soc. Jpn., 87, 365-379, 2009.

Umezawa, T., Machida, T., Aoki, S., and Nakazawa, T.: Contributions of natural and anthropogenic sources to atmospheric methane variations over western Siberia estimated from its carbon and hydrogen isotopes, Global Biogeochem. Cy., 26, GB4009, doi:10.1029/2011GB004232, 2012a.
Umezawa, T., Machida, T., Ishijima, K., Matsueda, H., Sawa, Y., Patra, P. K., Aoki, S., and Nakazawa, T.: Carbon and hydrogen isotopic ratios of atmospheric methane in the upper troposphere over the Western Pacific, Atmos. Chem. Phys., 12, 8095-8113, doi:10.5194/acp-12-8095-2012, 2012b.

Vermeulen, A. T., Hensen, A., Popa, M. E., van den Bulk, W. C. M., and Jongejan, P. A. C.: Greenhouse gas observations from Cabauw Tall Tower (1992-2010), Atmos. Meas. Tech., 4, 617644, doi:10.5194/amt-4-617-2011, 2011.

Wächter, H., Mohn, J., Tuzson, B., Emmenegger, L., and Sigrist, M. W.: Determination of $\mathrm{N}_{2} \mathrm{O}$ isotopomers with quantum cascade laser based absorption spectroscopy, Opt. Express, 16, 92399244, 2008.

WMO: 17th WMO/IAEA Meeting on Carbon Dioxide, Other Greenhouse Gases, and Related Measurement Techniques (GGMT-2013) 10-13 June 2013, GAW Report No. 213, World Meteorological Organization, Geneva, Switzerland, Beijing, China, 2014.

Wolf, B., Merbold, L., Decock, C., Tuzson, B., Harris, E., Six, J., Emmenegger, L., and Mohn, J.: First on-line isotopic characterization of $\mathrm{N}_{2} \mathrm{O}$ above intensively managed grassland, Biogeosciences, 12, 2517-2531, doi:10.5194/bg-12-2517-2015, 2015.

Yamada, K., Ozaki, Y., Nakagawa, F., Tanaka, M., and Yoshida, N.: An improved method for measurement of the hydrogen isotope ratio of atmospheric methane and its application to a Japanese urban atmosphere, Atmos. Environ., 37, 1975-1982, 2003.

Zazzeri, G., Lowry, D., Fisher, R. E., France, J. L., Lanoiselle, M., and Nisbet, E. G.: Plume mapping and isotopic characterisation of anthropogenic methane sources, Atmos. Environ., 110, 151$162,2015$. 